\title{
Metal Organic Frameworks for Hydrogen Purification
}

\author{
Donglai Mao ${ }^{1}$, John M Griffin ${ }^{2,3}$, Richard Dawson ${ }^{1}$, Alasdair Fairhurst ${ }^{4}$, Nuno Bimbo ${ }^{1,5^{*}}$ \\ ${ }^{1}$ Department of Engineering, Lancaster University, Lancaster LA1 4YW, United Kingdom \\ ${ }^{2}$ Department of Chemistry, Lancaster University, LA1 4YB, United Kingdom \\ ${ }^{3}$ Materials Science Institute, Lancaster University, LA1 4YB, United Kingdom \\ ${ }^{4}$ NanoSUN Limited, Lancaster, LA1 3NX, United Kingdom \\ ${ }^{5}$ Present address: School of Chemistry, University of Southampton, Southampton, SO17 1BJ, United Kingdom \\ *Corresponding Author: n.bimbo@soton.ac.uk
}

\begin{abstract}
High purity hydrogen is one of the key factors in determining the lifetime of proton exchange membrane (PEM) fuel cells. However, the current industrial processes for producing high purity hydrogen are not only expensive, but also come with low energy efficiencies and productivity. Finding more cost-effective methods of purifying hydrogen is essential for ensuring wider scale deployment of PEM fuel cells. Among various hydrogen purification methods, adsorption in porous materials and membrane technologies are seen as two of the most promising candidates for the current industrial hydrogen purification methods, with metal organic frameworks (MOF) being particularly popular in research over the last decade. Despite many available reviews on MOFs, most focus on synthesis and production, with few reports focused on performance for hydrogen purification. This review describes the working principle and performance parameters of adsorptive separations and membrane materials, and identifies MOFs that have been reported for hydrogen purification. The MOFs are summarized and their performance in separating hydrogen from common impurities $\left(\mathrm{CO}_{2}, \mathrm{~N}_{2}, \mathrm{CH}_{4}, \mathrm{CO}\right)$ is compared systematically. The challenges of commercial application of MOFs for hydrogen purification are discussed.
\end{abstract}

\section{Highlights:}

- Different types of metal organic frameworks that have been reported for $\mathrm{H}_{2}$ purification are summarised and compared.

- Metal organic frameworks with the highest $\mathrm{H}_{2}$ permeance value are identified.

- Metal organic frameworks with the highest overall $\mathrm{H}_{2}$ separation factors against various impurity gases are identified.

- Metal organic frameworks with a good balance of permeance and selectivity have been identified.

- Future research direction of metal organic frameworks for $\mathrm{H}_{2}$ purification is discussed.

Keywords: Metal Organic Frameworks, MOF, Hydrogen, Purification, ZIF, Zeolitic imidazolate frameworks, Adsorption

Word Count: 7152

\section{Introduction}

With the fast-growing world population, demand for energy has increased exponentially in the past few decades [1]. Despite the fact that they are inherently limited (see Table 1) [2], fossil fuels still account for $77.2 \%$ source of power generation globally (see Figure 1) [3]. In order to meet the energy demand and reduce greenhouse gas emissions, alternative energy sources such as geothermal, hydro, marine, solar, wind, and biomass are being utilized in greater quantities [2, 4]. However, the intermittent generation of electricity from such renewables sources gives rise to many challenges in managing grid demand [5]. To help solve the above issues, hydrogen-based energy system has been suggested by many researchers [6-8]. The system employs hydrogen as an energy carrier to transfer energy from various sources into electricity [9-12]. Hydrogen, one of the most promising vehicles through which a zero-carbon economy may be delivered, is abundant on Earth, does not produce harmful emissions at point of use and can be used to convert chemical to electrical energy efficiently in fuel cells. There are also multiple pathways to produce, store and convert hydrogen energy, allowing for great flexibility in 
both mobile and static applications [13-16]. However, it is worth noting that hydrogen is highly flammable and relevant safety measures should be put in place when handling hydrogen. This include installing hydrogen sensors, performing regular gas leakage checking on joints, separating energy management system controls from the operator, etc [17-19]. The system does not only have the advantage of clean emission, the high energy density per unit mass of hydrogen also helps smooth the fluctuations in renewable supply and match these with the inherent variability of market demand [16, 20-22]. In addition, with many countries investing in the development of hydrogen and fuel cells, the market value is expected to reach 11 billion USD by 2025 [16].

Table 1. Global fossil fuel statistics based on proved reserves (Adapted from [2])

*: End dates may shift ahead after new discoveries

\begin{tabular}{llll} 
Fuels & Total reserves & Production/day & $\begin{array}{l}\text { End } \\
\text { (date) }\end{array}$ \\
\hline Oil & 1.689 Trillion barrels & 86.81 Million barrels & 2066 \\
Gas & 6558 Trillion cubic feet & 326 Billion cubic feet & 2068 \\
Coal & 891.531 Billion tons & 21.63 Million tons & 2126 \\
\hline
\end{tabular}

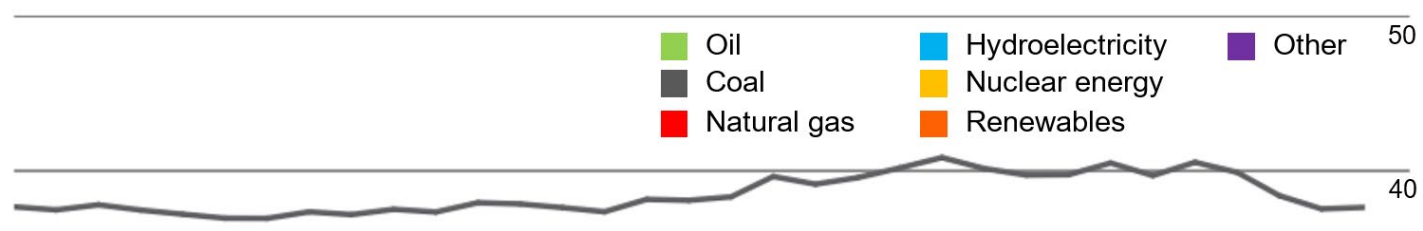

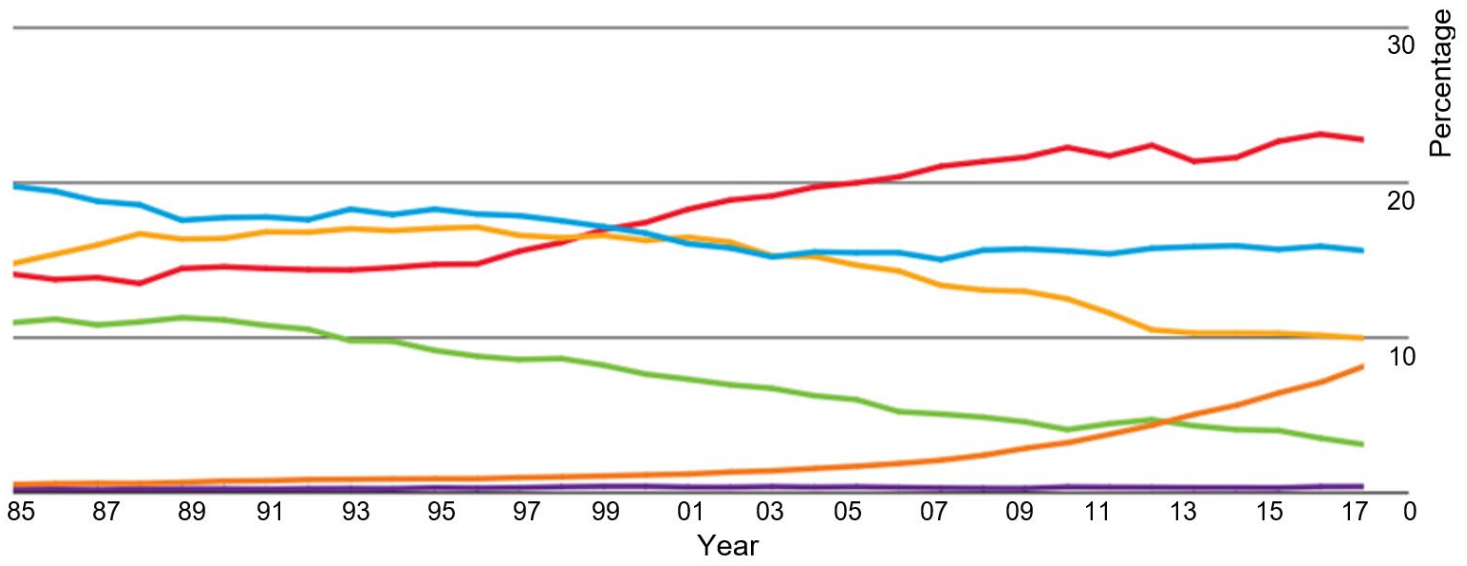

Figure 1. The share of global electricity generation by fuel (Percentage). Taken from [3].

Fuel cells are the most efficient method for converting energy using hydrogen. One of the most promising types of fuel cells is the proton-exchange membrane fuel cell (PEMFC). It has the advantages of fast start-up, high system efficiency $(40-50 \%$, compared to $20-35 \%$ for the internal combustion engines), and low working temperature, among others. Furthermore, with hydrogen being the primary fuel, it only generates water as a by-product with no harmful pollutants at point of use [13, 14]. However, it has a strict requirement for hydrogen purity, since only $10 \mathrm{ppm} C O$ impurities in hydrogen gas could cause a $28 \%$ decrease in the PEMFC performance $[15,23]$. Cheng et al have reviewed the influence of other contaminants on the performance of PEMFC, which was later summarized by Besancon et al in the form of a table (see Table 2) [24, 25]. The hydrogen fuel quality requirement for PEMFC applications in road vehicles has been specified by ISO 14687-2, according to which, high purity hydrogen is required for use in practical applications (see Table 3) [26]. 


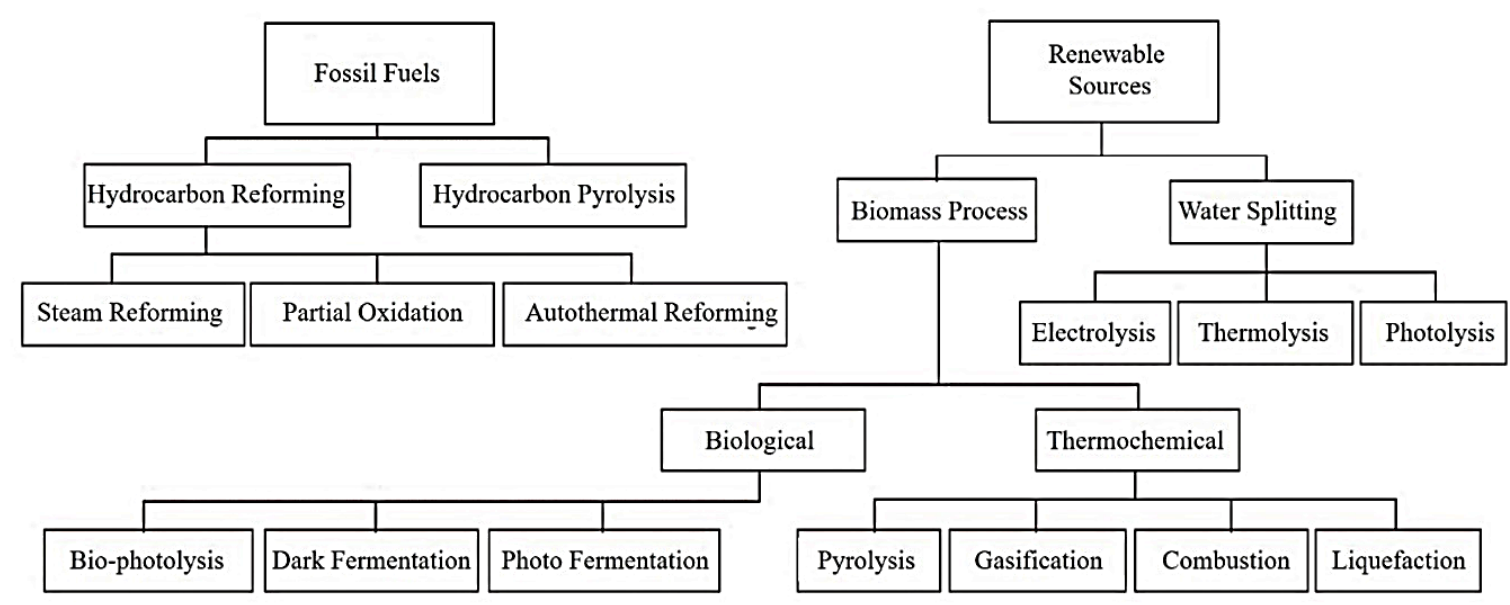

Figure 2. Hydrogen production methods summary. Reprinted from [27]. Copyright (2017), with permission from Elsevier.

Unfortunately, there is a very limited supply of molecular hydrogen on Earth, and they have to be produced from hydrogen-containing compounds such as hydrocarbons and water [28]. According to the source of feedstock (fossil fuels and renewable sources), hydrogen production methods have been categorised and summarised by Nikolaidis et al (see Figure 2) [27]. Despite the environmentally friendly appeal of producing hydrogen via methods utilising renewable sources (e.g. bio-photolysis process using biomass in Figure 2), they have the disadvantages of unsolved technological challenges and high costs in comparison to the methods using fossil fuels (e.g. steam reforming process in Figure 2). Therefore, the majority of industrial hydrogen are produced from fossil fuels using the corresponding methods as shown in Figure 2. The hydrogen from these processes can be purified in pressure swing adsorption columns (under temperatures of 21 to $38^{\circ} \mathrm{C}$ and pressures of 8- 28 bar [29]), but the resulting product contains impurities such as $\mathrm{CO}, \mathrm{CO}_{2}$, and other minor impurities (i.e. $\mathrm{O}_{2}, \mathrm{H}_{2} \mathrm{O}, \mathrm{N}_{2}, \mathrm{SO}_{x}, \mathrm{NO}_{x}$, sulfur-containing chemicals). Despite these purification steps, low quantities of impurities such as $\mathrm{CO}$ can still exist in the product [30-32]. Other hydrogen production methods, such as electrolysis of water and as a by-product of the chlor alkali process, will produce trace amounts of halogens such as chlorine, which without further purification will not meet the strict fuel quality requirements listed in Table 3 [13, 33]. Therefore, further hydrogen purification steps are essential to ensure that the hydrogen quality meets the fuel cell standard [25, 28, 34, 35].

Table 2. The influence of contaminants on PEM fuel cell performance (adapted from [25]).

Contaminant
Carbon monoxide $(\mathrm{CO})$
Sulfur compounds
Ammonia $\left(\mathrm{NH}_{3}\right)$
Carbon dioxide $\left(\mathrm{CO}_{2}\right)$
Hydrocarbons
Inert gases $\left(\mathrm{He}, \mathrm{Ar}, \mathrm{N}_{2}\right)$
Particulates
Water
Oxygen

\section{Impact on fuel cell performance}

Adsorbs to catalyst, degrades performance (reversible)

Adsorbs to catalyst, loss of performance (irreversible)

Degrades membrane ionomer conductivity

Tolerant at 100 ppm - limited CO back shifting

Aromatics, acids, aldehydes, etc. degrade performance

Dilution effect only

May degrade membrane

Tolerant to $>500 \mathrm{ppm}$

Tolerant to $>500 \mathrm{ppm}$

There are many methods for purifying hydrogen (see Table 4), some of which have been commercialized (e.g. cryogenic separation and pressure swing adsorption), with others still under development [36]. Although PSA and cryogenic processes are the main commercial methods to purify hydrogen, the product purity from both methods is generally not sufficient for fuel cell applications. Further PSA purification cycles can be conducted to improve purity however, this technique comes with a sacrifice in hydrogen recovery [37]. With the high cost associated with the energy requirement for both processes, membrane-based separation technologies have been explored by many researchers. They have the advantages of simple operation, low energy consumption, being environmentally friendly, 
amongst others. They are also considered promising methods for delivering high purity hydrogen [38, 39].

Table 3. Fuel quality requirements of hydrogen fuel for PEM fuel cells in road vehicles (Adapted from [26]).

$\begin{array}{ll}\begin{array}{ll}\text { Minimum hydrogen fuel index (mole fraction) } \\ \text { Maximum concentration of individual contaminants }\end{array} & 99.97 \% \\ \text { Contaminants } & \begin{array}{l}\text { Concentration: } \\ \text { mole fraction }\end{array} \\ \text { Total hydrocarbons ( } \mathrm{CH}_{4} \text { basis) } & 2 \mathrm{ppm} \\ \text { Oxygen } & 5 \mathrm{ppm} \\ \text { Helium } & 300 \mathrm{ppm} \\ \text { Total Nitrogen and Argon } & 100 \mathrm{ppm} \\ \text { Carbon dioxide } & 2 \mathrm{ppm} \\ \text { Carbon monoxide } & 0.2 \mathrm{ppm} \\ \text { Total sulphur compounds ( } \mathrm{H}_{2} \mathrm{~S} \text { basis) } & 0.004 \mathrm{ppm} \\ \text { Formaldehyde } & 0.01 \mathrm{ppm} \\ \text { Formic acid } & 0.2 \mathrm{ppm} \\ \text { Ammonia } & 0.1 \mathrm{ppm} \\ \text { Total Halogenated compounds (Halogen ion basis) } & 0.05 \mathrm{ppm}\end{array}$

Among the various types of porous materials for hydrogen purification, metal organic frameworks have received much attention over the last decade. Metal-organic frameworks (MOF) are a new type of porous material composed of metal ions or metal ion clusters, bonded by organic linkers. MOF materials have the advantages of high surface area, tuneable porosity, good selectivity, and flexible structures, which allow for performance adjustment, among other properties [40]. MOFs can also be used in the synthesis of nanostructured membranes, and many reports in this area have been published over the last few years. With the above advantages, extensive research has been carried out to study the material for various applications. According to Yin et al, some MOFs have already been applied for delivering gas and storing food commercially [41]. The main characteristics that make MOF popular in gas separation applications are:

(i) numerous possible combinations of metal centres and organic linkers;

(ii) potential to adjust pore sizes and inner surface properties through selecting metal centres and organic linkers, as well as using post-synthetic modification method;

(iii) higher pore volume with lower density [42].

Despite many reviews available for MOF materials, most focus on comparing synthesis methods, modification strategies, and production. Reviews on gas separation performance of the materials also exist, but they are in much shorter supply [42-47]. For example, Zhou et al reviewed the performance of MOFs materials in separating various gases. They categorised the MOFs according to the possible adsorption mechanisms and a wide range of gas mixture separation performance were summarised with $\mathrm{H}_{2}$ purification being a very small part of the paper [43]. Zhu et al reviewed synthesis method of MOFs membranes and their applications in separating both gases and liquids. Compared to the previous paper, there is a dedicated section reviewing hydrogen purification in this review. However, it is reported from the perspective of what materials have been reported instead of comparing their performance against each other [46]. Another review on MOFs membranes and their applications in gas separation was reported by Wang et al. However, this paper focus on the fabrication methods of MOFs and the issues associated with the corresponding methods [42]. Li summarised the recent progress in production and modification methods of MOFs membranes and the application of MOFs in various areas very comprehensively. Despite covering a wide range of research areas in MOFs, the performance of the materials in purifying $\mathrm{H}_{2}$ gas was mainly used to prove the effectiveness of different modification methods [47]. 
This review aims to systematically compare the performance of MOFs in separating hydrogen from common impurities e.g. $\mathrm{CO}_{2}, \mathrm{~N}_{2}, \mathrm{CH}_{4}$, etc., and reviews reports that have used MOFs in both their adsorbent form or in the synthesis of membranes. To our knowledge, the only paper that has extensively reviewed the performance of MOFs in separating $\mathrm{H}_{2}$ from other impurities during hydrogen production was reported by Azar et al. However, this paper only compares the performance of MOFs in separating $\mathrm{H}_{2}$ from $\mathrm{N}_{2}$. Other main impurities such as $\mathrm{CO}, \mathrm{CO}_{2}$, and $\mathrm{CH}_{4}$ were not mentioned [48]. As most of the hydrogen purification reports have focused on membranes, we will first show various separation mechanisms and performance parameters of membrane materials. Different MOFs that have been reported for hydrogen purification will then be compared systematically. Finally, we will summarize the current situation and discuss the future challenges of MOFs in hydrogen purification.

Table 4. Hydrogen purification technologies [36]

\begin{tabular}{|c|c|c|c|c|c|}
\hline Technique & Typical feed gas & $\begin{array}{l}\text { Purity } \\
(\%)\end{array}$ & $\begin{array}{l}\text { Recover } \\
\text { y }(\%)\end{array}$ & $\begin{array}{l}\text { Scale } \\
\text { of use }\end{array}$ & Comments \\
\hline $\begin{array}{l}\text { Cryo } \\
\text { Sep }\end{array}$ & $\begin{array}{l}\text { Petrochemical } \\
\text { and refinery off- } \\
\text { gases }\end{array}$ & $95-99$ & $90-98$ & $\begin{array}{l}\text { Large } \\
\text { scale }\end{array}$ & $\begin{array}{ll}\text { Pre-purification } & \text { step } \\
\text { necessary to remove } \mathrm{CO}_{2} \text {, } \\
\mathrm{H}_{2} \mathrm{~S} \text {, and water }\end{array}$ \\
\hline $\begin{array}{l}\text { Polymer } \\
\text { Membrane } \\
\text { Diffusion }\end{array}$ & $\begin{array}{l}\text { Refinery off-gases } \\
\text { and ammonia } \\
\text { purge gas }\end{array}$ & $92-98$ & $>85$ & $\begin{array}{l}\text { Small } \\
\text { to } \\
\text { large }\end{array}$ & $\begin{array}{l}\mathrm{He}, \mathrm{CO}_{2}, \mathrm{H}_{2} \mathrm{O} \text { may permeate } \\
\text { the membrane }\end{array}$ \\
\hline $\begin{array}{l}\text { Metal } \\
\text { Hydride } \\
\text { Separation }\end{array}$ & $\begin{array}{l}\text { Ammonia purge } \\
\text { gas }\end{array}$ & 99 & $5-95$ & $\begin{array}{l}\text { Small } \\
\text { to } \\
\text { mediu } \\
\mathrm{m}\end{array}$ & $\begin{array}{l}\text { yen adsorption poisoned } \\
\mathrm{N}_{2}, \mathrm{CO} \text {, and } \mathrm{S}\end{array}$ \\
\hline $\begin{array}{l}\text { Solid } \\
\text { Polymer } \\
\text { Electrolyte } \\
\text { cell }\end{array}$ & $\begin{array}{l}\text { Purification of } \\
\text { hydrogen } \\
\text { produced by } \\
\text { thermochemical } \\
\text { cycles }\end{array}$ & 99.8 & 95 & Small & $\begin{array}{l}\text { hpounds } \\
\text { ysts }\end{array}$ \\
\hline $\begin{array}{l}\text { Pressure } \\
\text { Swing } \\
\text { Adsorption }\end{array}$ & $\begin{array}{l}\text { Any hydrogen rich } \\
\text { gas }\end{array}$ & $>99.99$ & 70-90 & arge & $\begin{array}{l}\text { Relatively low recovery due to } \\
\text { hydrogen loss in the purging } \\
\text { step. }\end{array}$ \\
\hline $\begin{array}{l}\text { Catalytic } \\
\text { Purification }\end{array}$ & $\begin{array}{l}\text { Hydrogen streams } \\
\text { with oxygen } \\
\text { impurity }\end{array}$ & 9.999 & Jp to 99 & $\begin{array}{l}\text { Small } \\
\text { to } \\
\text { large }\end{array}$ & $\begin{array}{l}\text { Usually used to upgrade } \\
\text { electrolytic } \\
\text { organics, } \mathrm{Pd}-, \mathrm{Hg}-, \mathrm{Cd}-\text { and } \mathrm{S}- \\
\text { compounds poison the } \\
\text { catalyst. } \\
\mathrm{H}_{2} \mathrm{O} \text { produced }\end{array}$ \\
\hline $\begin{array}{l}\text { Palladium } \\
\text { Membrane } \\
\text { Diffusion }\end{array}$ & $\begin{array}{l}\text { Any hydrogen- } \\
\text { containing gas } \\
\text { stream }\end{array}$ & $\begin{array}{l}\geq \\
99.999 \\
9\end{array}$ & Up to 99 & $\begin{array}{l}\text { Small } \\
\text { to } \\
\text { mediu } \\
\mathrm{m}\end{array}$ & $\begin{array}{l}\text { Sulfur and CO-containing } \\
\text { compounds and unsaturated } \\
\text { hydrocarbon } \\
\text { permeability. }\end{array}$ \\
\hline
\end{tabular}

\section{Membrane gas separation mechanisms}

Most of the reports that have used MOFs for hydrogen purification have focused on their use as membranes. It is therefore helpful to know the possible gas separation mechanisms of membrane materials so that a better understanding can be developed. A membrane is a thin permeable film that is commonly used for separation and purification [49]. Membranes typically act as selective barriers, allowing only certain molecules to pass through the structure [50]. Several different mechanisms of separation exist, with some common examples being: (1) Poiseuille flow, (2) Knudsen diffusion, (3) molecular sieving, (4) capillary condensation, (5) surface diffusion, (6) solution-diffusion, and (7) facilitated transport. Figure 3 shows the above mechanisms in a schematic form [51, 52]. For membranes which are used to purify hydrogen, the main mechanisms are solution-diffusion and molecular sieving [51]. In the solution-diffusion mechanism, the main influencing factors are solubility and mobility of the gas molecules in the membrane. The most condensable molecules would show better solubility selectivity. At the same time, the smallest molecules tend to diffuse more quickly. Whereas in the molecular sieving mechanism, the main influencing factors are the size of the molecules, where the smallest molecules have a much higher diffusion rate. However, for molecules with similar sizes, factors such as sorption level have a strong impact on the diffusion rate [52]. 
Factors that influence the separation results using membranes include the relative size of molecules to be separated when compared to the pore size of the membrane, the solubility of molecules in the membrane, and dissociative diffusion mechanism [53]. In addition, factors such as partial pressure, concentration of target gases, temperature or electrical potential gradient also affect the process, with the partial pressure being the main driving force in practical applications [54].

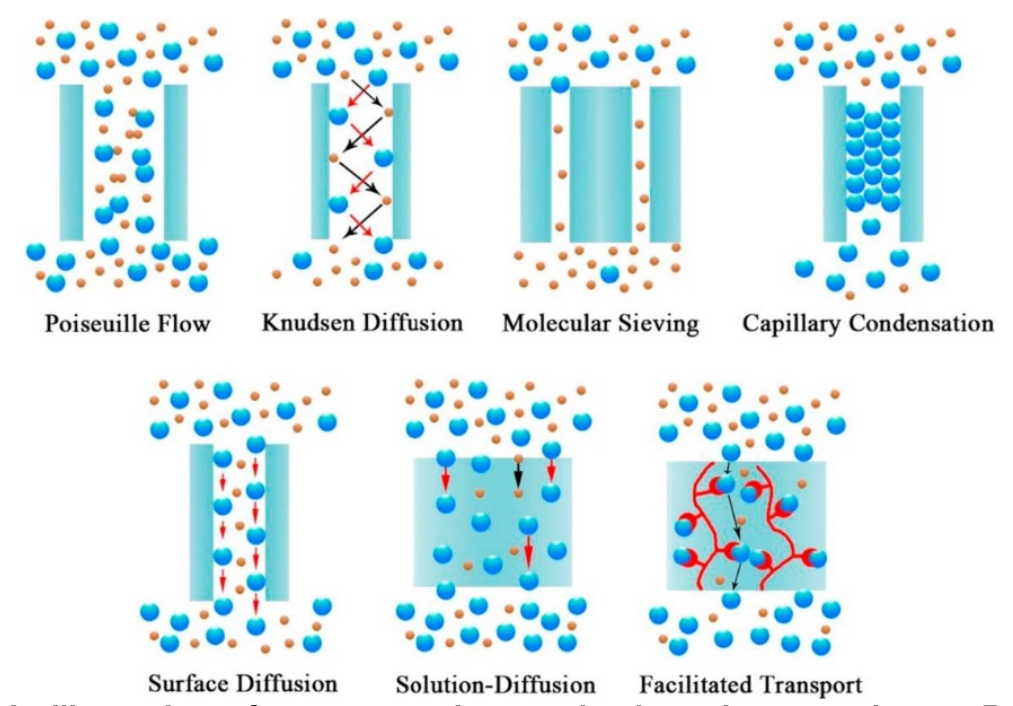

Figure 3. Schematic illustration of gas separation mechanisms in a membrane. Reprinted from [51]. Copyright (2015), with permission from Elsevier.

\section{Performance parameters}

The main parameters used to assess the performance of a membrane are permeability and selectivity. Permeability indicates the tendency of component flux through the membrane. It equals the product of diffusion coefficient $(D)$ and solubility coefficient $(S)$ of gas in membranes as shown in equation (1).

$$
P=D \times S
$$

$P$ : permeability, unit: $\mathrm{cm}^{3}(\mathrm{STP}) \mathrm{cm} / \mathrm{cm}^{2} \mathrm{~s} \mathrm{cmHg}$

$D$ : diffusion coefficient, unit: $\mathrm{cm}^{2} / \mathrm{s}$

S: solubility coefficient, unit: $\mathrm{cm}^{3}(\mathrm{STP}) /\left(\mathrm{cm}^{3} \mathrm{cmHg}\right)$

where $D$ is a kinetic parameter and $S$ is a thermodynamic parameter. $D$ is related to the size of the gas molecule, whereas $S$ is associated with the condensability of gas and the interaction between the gas and the membrane. Using materials with higher permeability would lead to better productivity $[51,55-$ 57].

Selectivity shows the ability of a membrane in separating gases. The ideal selectivity of a membrane separating gas $A$ and gas $B$ is shown in equation (2):

$\alpha_{\mathrm{A} / \mathrm{B}}=\frac{P_{A}}{P_{B}}=\frac{D_{A}}{D_{B}} \times \frac{S_{A}}{S_{B}}=\alpha_{\mathrm{A} / \mathrm{B}}^{D} \times \alpha_{\mathrm{A} / \mathrm{B}}^{S}$

where $P_{A}$ and $P_{B}$ are the permeability of gas $A$ and gas $B$ respectively; $D_{A}, D_{B}, S_{A}$, and $S_{B}$ are the diffusion and solubility coefficients of $A$ and $B$ in the membrane respectively; $\alpha_{A / B}^{D}\left(\frac{D_{A}}{D_{B}}\right)$ is the diffusion selectivity representing the molecular size difference of $A$ and $B$, whereas $\alpha_{A / B}^{S}\left(\frac{S_{A}}{S_{B}}\right)$ is the solubility selectivity showing the adsorption preferences of one gas over the others. Materials with higher selectivity tend to produce hydrogen with greater purity. However, this may mean lower productivity [51, 55-57]. Factors that influence these two parameters include temperature, pressure, humidity, gas compositions, and others [58, 59].

It is worth noting that permeability and selectivity can be used for direct comparison of membranes. However, when choosing membrane materials for commercial applications, fundamental science of the 
corresponding material and the scaling up potential should also be considered, since it varies between different membranes [60].

\section{MOFs for hydrogen purification}

When applied for gas separations, MOFs have been studied in the form of crystalline powders, pelletized systems, and as membranes. MOF materials that have been reported for hydrogen purification include MOF-5, ZIF-7, ZIF-8, ZIF-90, CuBTC, COF, NH $2-M I L-53$, MOF-74, UiO-66, etc. Their performance in hydrogen purification is summarized in Table 7, along with the corresponding references. In this section, the permeance and separation factors of the materials are compared. The comparison of separation factors should be used as a guide only when they are obtained by prediction with computer simulation models. This is because the validation of the corresponding data is much more complex for multicomponent adsorption isotherms. General MOF reviews can be found in references $[42,43,46,47]$.

\subsection{MOF with multi-carboxylate groups}

Multi-carboxylate ligands, benzene-multicarboxylate in particular, are widely used as organic linkers in MOFs. Some of the most commonly used benzene-multicarboxylate linkers are:

- benzene-1,4-dicarboxylate (BDC)

- benzene-1,3-dicarboxylate (IP, as in isophtalic acid)

- benzene-1,3,5-tricarboxylate (BTC)

More details about the roles of these ligands can be found in reference [61] . Here, we mainly focus on the MOFs with these ligands that have been reported for hydrogen separation. These materials are MOF-5, MIL-53 (AI), NH $2-M I L-53(A I)$, CuBTC/MIL-100, and CuBTC.

\subsubsection{MOF-5}

MOF-5 is also known as IRMOF-1(isoreticular metal organic framework) and its molecular formula is $\mathrm{Zn}_{4} \mathrm{O}(\mathrm{BDC})_{3}$. Compared to other MOF materials, there are a limited number of reports using this material for hydrogen purification [62]. When MOF-5 was first reported for hydrogen purification, its separation factors were reported as following Knudsen diffusion with a permeance value of $3.00 \times 10^{-6}$ mol s${ }^{-1} \mathrm{~m}^{-2} \mathrm{~Pa}^{-1}$ [62]. Later, the same research group used a different method and synthesised preferentially-oriented MOF-5 membranes. The newly reported MOF-5 showed a lower permeance value than before $\left(8.00 \times 10^{-7} \mathrm{~mol} \mathrm{~s}^{-1} \mathrm{~m}^{-2} \mathrm{~Pa}^{-1}\right)$. The selectivity of the material for various gases (see Table 15) was reported to be consistent with the previous study [63].

Another paper on MOF-5 for hydrogen purification application was reported by Lin et al [64]. The permeance of this material is lower than what was reported by Lai et al [62]. This is not surprising considering the pore size of the sample is smaller $(8 \AA)$ than what was reported by Lai et al $(15.6 \AA)$ [63]. Despite being higher in value than what was reported earlier, the separation factors of various gases in this report are ideal separation factors. The experimental value of separation factors are unknown. It is therefore difficult to compare the performance of MOF-5 with other reports.

The most recent report using MOF-5 to separate hydrogen from other impurities was published by Kloutse et al in 2018, and was based on powder adsorbent materials, with the performance measured using a recirculating volumetric method. This is also one of the few papers reporting the performance of MOFs in separating ternary mixtures $\left(\mathrm{H}_{2}: \mathrm{N}_{2}: \mathrm{CO}_{2}=45 \%: 45 \%: 10 \%\right.$ and $\mathrm{H}_{2}: \mathrm{CH}_{4}: \mathrm{CO}_{2}=42.5 \%: 15 \%: 42.5 \%$ ) under different pressures (up to $1000 \mathrm{kPa}$ at $297 \mathrm{~K}$ ) instead of binary mixtures. It was found that the order of gas adsorption for MOF-5 is $\mathrm{CO}_{2}>\mathrm{CH}_{4}>\mathrm{N}_{2}>\mathrm{H}_{2}$. In addition, the quantity of gas adsorption rises with pressure. Similar results are seen with CuBTC, tested as part of the same study. It is worth noting that azeotropic behaviour was observed for $\mathrm{N}_{2}$ and $\mathrm{CO}_{2}$ in $\mathrm{H}_{2}-\mathrm{N}_{2}-$ $\mathrm{CO}_{2}$ gas mixture with both MOFs, that is, their selectivities changed with composition. This was connected to a high deviation in separation factors when comparing the results from ternary and equivalent binary mixtures. The authors suggest this was caused by a competition between $\mathrm{CO}_{2}$ and $\mathrm{N}_{2}$ when they were adsorbed by MOFs. However, this was not observed for the $\mathrm{H}_{2}-\mathrm{CH}_{4}-\mathrm{CO}_{2}$ gas mixtures [65].

\subsubsection{MIL-n}

One type of carboxylate containing MOF is the MIL-n (MIL: Materials Institute Lavoisier) type with trivalent cations. These types of MOFs have topologies that are similar to zeolites. However, they have different surface chemistry, density and pore sizes [61]. 
Aluminium 1, 4-benzene-dicarboxylate is normally known as MIL-53 (Al). Its framework consists of infinite chains of corner-sharing $\mathrm{AlO}_{4}(\mathrm{OH})_{2}$ octahedral. It is famous for its exceptional flexibility, which allows for reversible cell volume adjustment. This leads to better interactions between the guest molecules and the framework. Other advantages of the material include high thermal and chemical stability [66]. The MIL-53 type material that showed the best performance in separating hydrogen from other impurity gases is $\mathrm{NH}_{2}-\mathrm{MIL}-53$ reported by Li et al. The material had large pore sizes of $7.5 \AA$, which contributed to its relatively high permeance. With a thickness of $8 \mu \mathrm{m}$, the membrane showed permeance of $5.42 \times 10^{-6} \mathrm{~mol} \mathrm{~s}^{-1} \mathrm{~m}^{-2} \mathrm{~Pa}^{-1}$ for $\mathrm{H}_{2}$ and $4.21 \times 10^{-6} \mathrm{~mol} \mathrm{~s}^{-1} \mathrm{~m}^{-2} \mathrm{~Pa}^{-1} \mathrm{for}_{2} / \mathrm{CO}_{2}$. The ideal separation factors of the material were 32.4 for $\mathrm{H}_{2} / \mathrm{CO}_{2}$, 27.9 for $\mathrm{H}_{2} / \mathrm{N}_{2}$, and 27.3 for $\mathrm{H}_{2} / \mathrm{CH}_{4}$ [67].

Another MIL- $n$ type MOF that showed good performance in separating hydrogen from other impurity gases is CuBTC/MIL-100 fabricated by transforming CuBTC into CuBTC/MIL-100. The above process was achieved by immersing CuBTC hollow fibre into $\mathrm{FeCl}_{3} \cdot 6 \mathrm{H}_{2} \mathrm{O}$ methanol solution so that the $\mathrm{Fe}^{3+}$ ions could substitute less stable $\mathrm{Cu}^{2+}$ ions in CuBTC. The achieved membrane was $20 \mu \mathrm{m}$ thick and showed $\mathrm{H}_{2}$ permeance of $8.8 \times 10^{-8} \mathrm{~mol} \mathrm{~m}^{-2} \mathrm{~s}^{-1} \mathrm{~Pa}^{-1}$. Despite the low permeance, the membrane showed very high selectivities in hydrogen separation: 77.6 for $\mathrm{H}_{2} / \mathrm{CO}_{2}, 217.0$ for $\mathrm{H}_{2} / \mathrm{N}_{2}$ and 335.7 for $\mathrm{H}_{2} / \mathrm{CH}_{4}$. In addition, the selectivities and permeance increased with higher temperature. At $85^{\circ} \mathrm{C}$, the $\mathrm{H}_{2}$ permeance was $10.5 \times 10^{-8} \mathrm{~mol} \mathrm{~m}^{-2} \mathrm{~s}^{-1} \mathrm{~Pa}^{-1}$ with $\mathrm{H}_{2} / \mathrm{CO}_{2}$ and $\mathrm{H}_{2} / \mathrm{N}_{2}$ selectivities being 89.0 and 240.5 respectively. The membrane was able to maintain its high performance for over $192 \mathrm{~h}$ [68].

\subsubsection{CuBTC}

Copper benzene-1,3,5-tricarboxylate (CuBTC) is also known as HKUST-1, $\mathrm{Cu}_{3}(\mathrm{BTC})_{2}$, MOF-199, and Basolite (TM) C300. Different from ZIFs, CuBTC possesses large pores of $9 \AA$. Apart from ZIF-8, it is the second most frequently reported MOF for hydrogen purification.

The highest permeance of CuBTC $\left(7.05 \times 10^{-5} \mathrm{~mol} \mathrm{~m}^{-2} \mathrm{~s}^{-1} \mathrm{~Pa}^{-1}\right)$ was reported by Li et al. CuBTC was growing on polyacrylonitrile (PAN) to form a $\mathrm{Cu}_{3}(\mathrm{BTC})_{2}-\mathrm{PAN}$ hollow fiber membrane via a chemical modification process. The membrane was $13 \mu \mathrm{m}$ in thickness with a $\mathrm{H}_{2} / \mathrm{CO}_{2}$ separation factor of 7.1 at $20^{\circ} \mathrm{C}[69]$.

Although most reported CuBTC membranes showed $\mathrm{H}_{2} / \mathrm{CO}_{2}$ separation factors that were lower than 10 , Zhou et al reported a CuBTC membrane which showed a $\mathrm{H}_{2} / \mathrm{CO}_{2}(1: 1 \mathrm{v} / \mathrm{v})$ separation factor of 13.6 at $40^{\circ} \mathrm{C}$. The material was $13 \mu \mathrm{m}$ thick with $\mathrm{H}_{2} / \mathrm{CO}_{2}(1: 1 \mathrm{v} / \mathrm{v})$ and $\mathrm{H}_{2} / \mathrm{CH}_{4}(1: 1 \mathrm{v} / \mathrm{v})$ separation factors of 6.8 and 6.19 respectively. Unfortunately, the permeance of the membrane was relatively low $(4.10 \mathrm{x}$ $10^{-8} \mathrm{~mol} \mathrm{~m}^{-2} \mathrm{~s}^{-1} \mathrm{~Pa}^{-1}$ for $\mathrm{H}_{2}$ in a binary gas mixture) compared to other reports [70].

The highest ideal $\mathrm{H}_{2} / \mathrm{N}_{2}$ separation factor for CuBTC (13.7 at room temperature) was reported by Shah et al. The CuBTC membrane was prepared by a rapid thermal deposition process, which was relatively less time consuming than other traditional fabrication methods (i.e. in situ and secondary growth). With a thickness of between 20 and $25 \mu \mathrm{m}$, the material also showed an ideal $\mathrm{H}_{2} / \mathrm{CH}_{4}$ separation factor of 8.8. It is also worth noting that the permeance of the membrane (approximately $3.0 \times 10^{-7} \mathrm{~mol} \mathrm{~m}^{-2} \mathrm{~s}^{-1}$ $\mathrm{Pa}^{-1}$ ) was poor [71].

The highest reported $\mathrm{H}_{2} / \mathrm{CH}_{4}(1: 1 \mathrm{v} / \mathrm{v})$ separation factor for CuBTC is 11.2 measured at $25{ }^{\circ} \mathrm{C}$. The support material for the CuBTC in this report was stainless steel coated with poly(methyl methacrylate) (PMMA) and poly(methacrylic acid) (PMAA). The membrane was approximately $13 \mu \mathrm{m}$ thick with relatively high permeance of $1.29 \times 10^{-6} \mathrm{~mol} \mathrm{~m}^{-2} \mathrm{~s}^{-1}$. One interesting aspect of this membrane was that it showed higher $\mathrm{H}_{2} / \mathrm{CH}_{4}$ separation factor than $\mathrm{H}_{2} / \mathrm{CO}_{2}(9.24$ for $1: 1 \mathrm{v} / \mathrm{v})$ and $\mathrm{H}_{2} / \mathrm{N}_{2}(8.91$ for $1: 1 \mathrm{v} / \mathrm{v})$. This is different from other reported CuBTC, which generally showed the highest separation factor for $\mathrm{H}_{2} / \mathrm{CO}_{2}$ followed by $\mathrm{H}_{2} / \mathrm{N}_{2}$ and $\mathrm{H}_{2} / \mathrm{CH}_{4}$ (see Table 7 ). This could be attributed to the polymer coatings on the support material [72].

\subsubsection{M-MOF-74}

M-MOF-74 is known for its flexibility of accommodating various divalent ions. The metal ions can be one type of ions only or a mixture of different ions [73]. Compared to other MOFs, isostructural M-MOF74 has larger pore sizes $(11 \AA)$. This indicates molecular sieving effect is insignificant during gas separation [74]. There are two main types of MOF-74 reported for hydrogen purification: Mg-MOF-74 (also known as $\mathrm{Mg}_{2}$ (dobdc) or CPO-27-Mg) and Ni-MOF-74. This section will discuss the performance of these two materials that have been reported for hydrogen separation.

Herm et al (2011) tested single component $\mathrm{CO}_{2}$ and $\mathrm{H}_{2}$ adsorption isotherms of three types of MOFs: 
(i) High surface area and rigid framework structure: $\mathrm{Zn}_{4} \mathrm{O}(\mathrm{BTB})_{2}$ (MOF-177, $\mathrm{BTB}^{3-}=1,3,5-$ benzenetribenzoate) and $\mathrm{Be}_{12}(\mathrm{OH})_{12}(\mathrm{BTB})_{4}(\mathrm{Be}-\mathrm{BTB})$

(ii) High surface area and flexible framework: $\mathrm{Co}(\mathrm{BDP})\left(\mathrm{BDP}^{2-}=1,4\right.$-benzenedipyrazolate)

(iii) Surfaces coated with exposed metal cations: $\mathrm{H}_{3}\left[\left(\mathrm{Cu}_{4} \mathrm{Cl}\right)_{3}(\mathrm{BTTri})_{8}\right]\left(\mathrm{Cu}-\mathrm{BTTri}\right.$, BTTri ${ }^{3-}=$ 1,3,5-benzenetristriazolate) and $\mathrm{Mg}_{2}$ (dobdc) $\quad$ (dobdc $^{4-}=$ 1,4-dioxido-2,5benzenedicarboxylate)

Using ideal adsorbed solution theory (IAST), the authors evaluated the $\mathrm{H}_{2} / \mathrm{CO}_{2}$ selectivity of the above materials for different $\mathrm{H}_{2}: \mathrm{CO}_{2}$ ratios (80:20 for hydrogen purification and $60: 40$ for precombustion $\mathrm{CO}_{2}$ capture) under different conditions. The ideal $\mathrm{CO}_{2} / \mathrm{H}_{2}$ selectivity for $80: 20\left(\mathrm{H}_{2}: \mathrm{CO}_{2}\right)$ mixture is shown in Figure 4. Compared to other MOFs, $\mathrm{Mg}_{2}$ (dobdc) showed the highest selectivities followed by Cu-BTTri, which is also from group III. The author suggested that MOFs with exposed metal cation sites tend to have higher $\mathrm{H}_{2} / \mathrm{CO}_{2}$ selectivities [75].

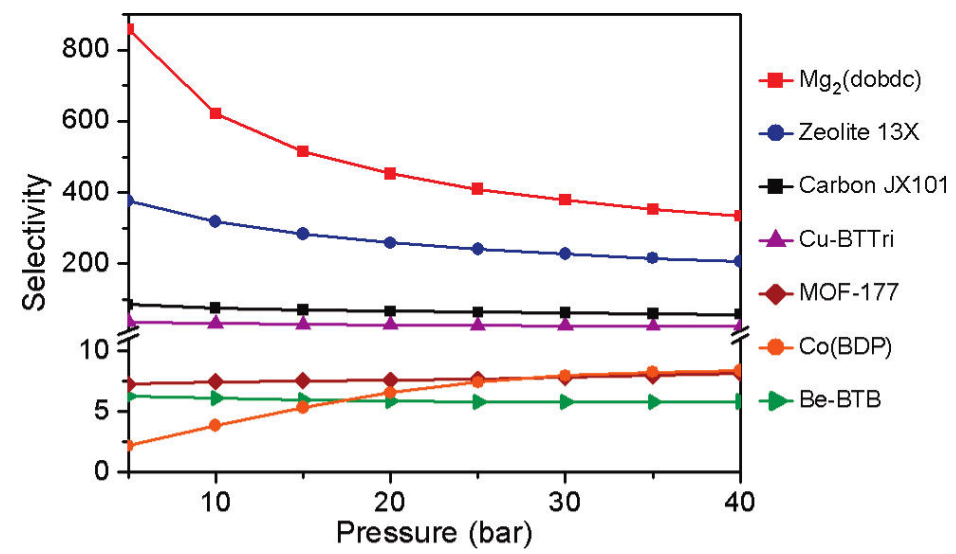

Figure 4. IAST $\mathrm{CO}_{2} / \mathrm{H}_{2}$ selectivities for a $80: 20 \mathrm{H}_{2} / \mathrm{CO}_{2}$ mixture at $313 \mathrm{~K}$, as calculated from gas sorption isotherms collected for the metal-organic frameworks MOF-177, Be-BTB, Co(BDP), Cu-BTTri, and $\mathrm{Mg}_{2}$ (dobdc), activated carbon JX101, and zeolite 13X. Reprinted with permission from [75]. Copyright (2011) American Chemical Society.

In 2012, the same group measured $\mathrm{CH}_{4}$ adsorption isotherms of $\mathrm{Mg}_{2}$ (dobdc) under high pressures. Using the same method, the authors evaluated the selectivity and working capacity of the material for separating gas mixtures of $\mathrm{CO}_{2} / \mathrm{CH}_{4}(1: 1 \mathrm{v} / \mathrm{v}), \mathrm{CH}_{4} / \mathrm{H}_{2}(1: 1 \mathrm{v} / \mathrm{v})$ and $\mathrm{CO}_{2} / \mathrm{CH}_{4} / \mathrm{H}_{2}(1: 4: 20)$. The result was compared to $13 \mathrm{X}$ zeolite, which showed that the material exhibited $50-75 \%$ higher selectivities and almost twice the working capacity of $13 \mathrm{X}$ zeolite. In addition, the material regeneration was promising, making it a good candidate for purifying hydrogen [76]. Krishna et al reported similar performance for the material [77].

However, Liu et al tested the stability of both Mg-MOF-74 and Ni-MOF-74 on $\mathrm{CO}_{2}$ adsorption and reported that Mg-MOF-74 was less stable and lost considerable amount of $\mathrm{CO}_{2}$ adsorption capacity in the presence of water vapour. The reported cause was the preferential oxidation of $\mathrm{Mg}$ over $\mathrm{Ni}$ in the material [78].

Following the above reports, Lee et al reported using a two-stage synthesis method to synthesize defect-free Ni-MOF-74 membranes on $\alpha$-alumina supports. The obtained material showed a high BET surface area of $1318 \mathrm{~m}^{2} / \mathrm{g}$ and was able to remain stable at $400^{\circ} \mathrm{C}$. With a thickness of $25 \mu \mathrm{m}$, the membrane exhibited permeance of $1.27 \times 10^{-5} \mathrm{~mol} \mathrm{~m}^{-2} \mathrm{~s}^{-1} \mathrm{~Pa}^{-1}$. According to the single gas permeation measurements, the ideal $\mathrm{H}_{2} / \mathrm{CO}_{2}, \mathrm{H}_{2} / \mathrm{N}_{2}$ and $\mathrm{H}_{2} / \mathrm{CH}_{4}$ separation factors of Ni-MOF-74 membrane were $9.1,3$, and 2.9 respectively. The author compared the results to data from other reports (see Table 5) and concluded that Ni-MOF-74 showed the highest $\mathrm{H}_{2} / \mathrm{CO}_{2}$ selectivity [79]. This conclusion may require re-evaluation given the advancement of research into more novel MOFs. For example, Wang et al modified Mg-MOF-74 membrane via amination of the open $\mathrm{Mg}$ sites in the material. $\mathrm{The}^{\mathrm{H}} \mathrm{H} / \mathrm{CO}_{2}$ separation factor of the material increased from 10.5 to 28 after the modification. This is much higher than Ni-MOF-74. However, despite being thinner, the permeance of the membrane is significantly lower $\left(2.7 \times 10^{-9} \mathrm{~mol} \mathrm{~m}^{-2} \mathrm{~s}^{-1} \mathrm{~Pa}^{-1}\right)$ than Ni-MOF-74 (10 $\mu \mathrm{m}$ thick) [74]. 
Table 5. Comparison of gas separation performance of Ni-MOF-74 membrane with other membranes. Adapted from [79].

\begin{tabular}{|c|c|c|c|c|c|c|}
\hline \multirow[t]{2}{*}{ Membrane } & \multirow[t]{2}{*}{ Pore size (nm) } & \multicolumn{4}{|c|}{ Single gas separation performance selectivity } & \multirow{2}{*}{$\begin{array}{l}\text { Permeance } \\
\left(\mathrm{mol} \mathrm{m}^{-2} \mathrm{~s}^{-1} \mathrm{~Pa}^{-1}\right)\end{array}$} \\
\hline & & $\mathrm{H}_{2} / \mathrm{CO}_{2}$ & $\mathrm{H}_{2} / \mathrm{N}_{2}$ & $\mathrm{H}_{2} / \mathrm{CH}_{4}$ & $\mathrm{CO}_{2} / \mathrm{N}_{2}$ & \\
\hline Polymers & - & - & - & 10 & - & $10^{-12}$ \\
\hline MMOF & 0.32 & - & $25^{[a]}$ & - & 1 & $10^{-9}$ \\
\hline ZIF-7 & 0.30 & $4 \sim 7$ & - & - & - & $10^{-8}$ \\
\hline ZIF-8 & 0.34 & $4 \sim 7$ & - & - & $2 \sim 3$ & $10^{-8}$ \\
\hline Silicate(1) & 0.55 & $4.4^{[a]}$ & - & $2.1^{[a]}$ & - & $10^{-7}$ \\
\hline Silicate(2) & 0.55 & $1.8^{[\mathrm{a}]}$ & $3.1^{[a]}$ & $1.8^{[a]}$ & - & $10^{-7}$ \\
\hline B-ZSM-5 & 0.55 & $2^{[a]}$ & - & $5.8^{[\mathrm{a}]}$ & - & $10^{-7}$ \\
\hline Cu-BTC(1) & 0.9 & 4.5 & 4.6 & 7.8 & 1 & $10^{-6}$ \\
\hline Cu-BTC(2) & 0.9 & 5.1 & 3.7 & 2.9 & & $10^{-7}$ \\
\hline Ni-MOF-74 & 1.58 & 9.1 & 3 & 2.9 & 3 & $10^{-6}$ \\
\hline
\end{tabular}

[a] $200^{\circ} \mathrm{C}$.

In addition, the Ni-MOF-74 material reported by Al-Naddaf et al showed much higher ideal selectivity values than the other reported M-MOF-74 materials for $\mathrm{H}_{2}$ purification. In this report, Ni-MOF-74 was grown on top of zeolites to form a core-shell composite (see Figure 5). The author tested samples with different ratios of Ni-MOF-74 and zeolite. The ideal selectivity values of the samples are shown in Table 6 . The author concluded that sample consisted of $95 \%$ MOF-74 as the shell and $5 \%$ zeolite as the core (Zeo-A@MOF-74-1) showed the best performance compared to zeolite or Ni-MOF-74 in separating hydrogen from corresponding impurities [80].

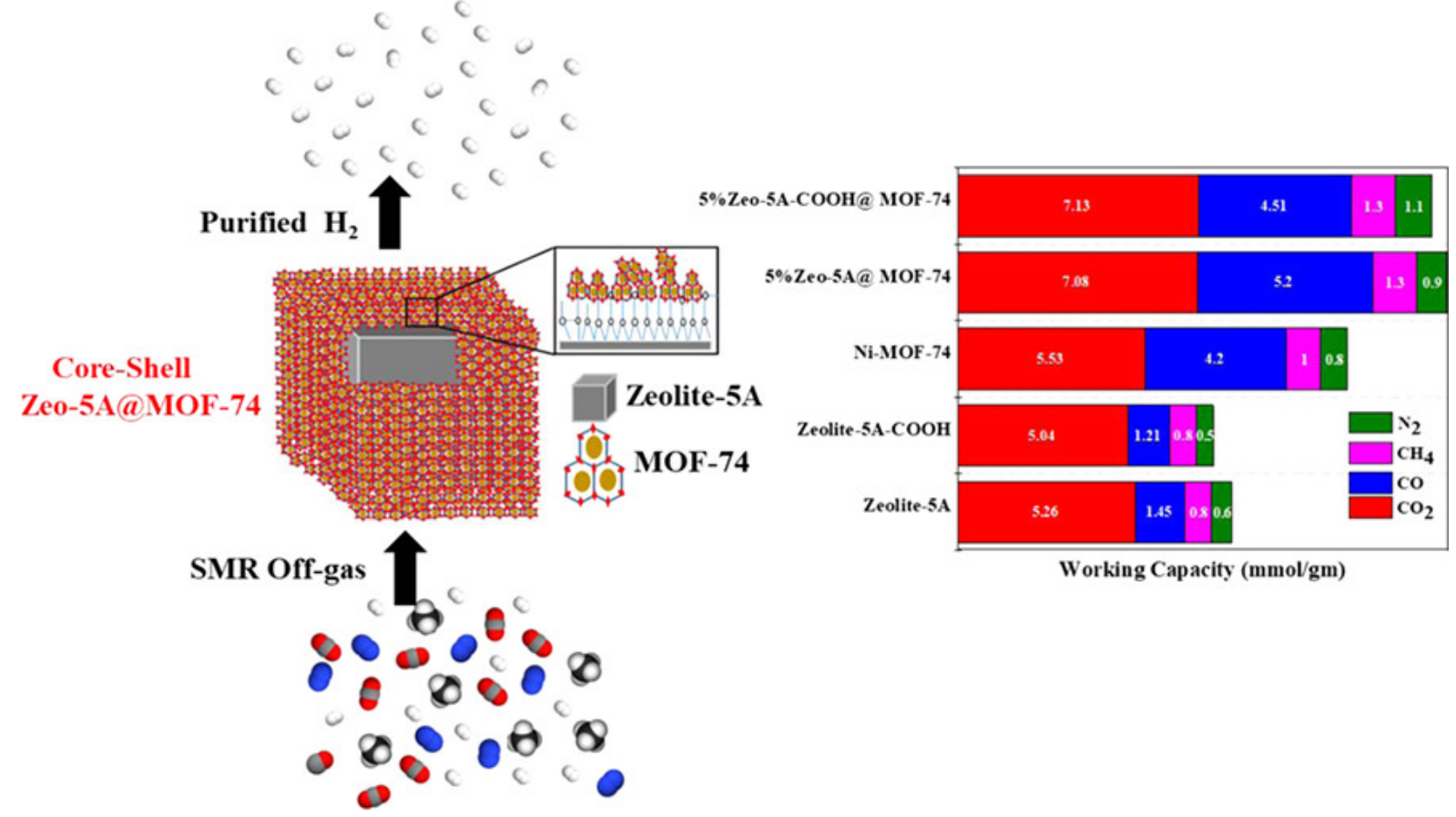

Figure 5. Schematic illustration of core-shell structure of Zeo-A@MOF-74-1 and its gas adsorption capacities. Reprinted with permission from [80]. Copyright (2018) American Chemical Society.

Table 6. Estimated selectivity values for $\mathrm{CO}_{2} / \mathrm{H}_{2}, \mathrm{CO} / \mathrm{H}_{2}, \mathrm{CH}_{4} / \mathrm{H}_{2}$, and $\mathrm{N}_{2} / \mathrm{H}_{2}$. Adapted from [80].

\begin{tabular}{lllll} 
Adsorbent & $\mathrm{CO}_{2} / \mathrm{H}_{2}$ & $\mathrm{CO} / \mathrm{H}_{2}$ & $\mathrm{CH}_{4} / \mathrm{H}_{2}$ & $\mathrm{~N}_{2} / \mathrm{H}_{2}$ \\
\hline Ni-MOF-74 & 1084 & 3903 & 14 & 12 \\
zeolite-5A & 15627 & 796 & 204 & 173 \\
zeolite-5A-COOH & 2444 & 65 & 25 & 14 \\
Zeo-A@MOF-74-1 & 8659 & 24375 & 114 & 45 \\
Zeo-A@MOF-74-2 & 1984 & 7039 & 33 & 25
\end{tabular}




$\begin{array}{lllll}\text { Zeo-A@MOF-74-3 } & 1514 & 5321 & 29 & 20 \\ \text { Zeo-B@MOF-74-1 } & 1984 & 4624 & 20 & 13 \\ \text { Zeo-B@MOF-74-2 } & 1329 & 2219 & 13 & 12 \\ \text { Zeo-B@MOF-74-3 } & 860 & 1695 & 12 & 10\end{array}$

\subsubsection{UiO-66}

The molecular formula of UiO-66 (Universitetet i Oslo) is $\mathrm{Zr}_{6} \mathrm{O}_{4}(\mathrm{OH})_{4}(\mathrm{bdc})_{6}$. This material has the advantages of high chemical, thermal and mechanical stabilities. Banu et al used Grand canonical Monte Carlo and molecular dynamics simulations to determine the potential of zirconium oxide based MOFs (ehydroxylated $\mathrm{UiO}-66(\mathrm{Zr})$, UiO-66(Zr)- $\mathrm{Br}$, UiO67( $\mathrm{Zr}$ ), and $\mathrm{Zr}-\mathrm{Cl}_{2} \mathrm{AzoBDC}$ ) for purifying hydrogen in steam methane reforming (SMR) off-gas [81]. The results were compared to the performance of a commercial 5A zeolite and activated carbon. It was found that UiO-66(Zr) showed the highest working capacities for $\mathrm{CO}_{2}$ and $\mathrm{CH}_{4}$ (pressure range: 1-7 bar) due to its large relative pore volume (see Figure 6). The selectivities of the samples were evaluated using binary mixtures. The $\mathrm{H}_{2} /$ impurity ratio in binary gases was 70/30. It was found that UiO-66( $\mathrm{Zr}$ )-Br showed the highest $\mathrm{N}_{2}$ and $\mathrm{CO}$ selectivities and working capacities due to its small and functionalised pores (see Figure 7). According to the breakthrough curve simulations, $\mathrm{UiO}-66(\mathrm{Zr})$ and $\mathrm{UiO}-66(\mathrm{Zr})-\mathrm{Br}$ exhibited longer breakthrough time than the other materials with UiO-66(Zr)-Br showing the longest time. This indicates these two materials would deliver a larger quantity of hydrogen. By comparing various factors, $\mathrm{UiO}-66(\mathrm{Zr})-\mathrm{Br}$ was suggested as the most promising adsorbent material [81].

Friebe et al synthesised UiO-66 membrane with pore sizes of $6 \AA$ on $\alpha-\mathrm{Al}_{2} \mathrm{O}_{3}$ supports ( $5 \mu \mathrm{m}$ thick). The experimentally determined gas permeance is shown in Figure 8 . The separation factors for various gas mixtures were $\mathrm{H}_{2} / \mathrm{CO}_{2}(1: 1 \mathrm{v} / \mathrm{v})=5.1, \mathrm{H}_{2} / \mathrm{N}_{2}(1: 1 \mathrm{v} / \mathrm{v})=4.7$, and $\mathrm{H}_{2} / \mathrm{CH}_{4}(1: 1 \mathrm{v} / \mathrm{v})=12.9$ [82], although it seemed that the experimentally obtained separation factors are significantly lower than the theoretical separation factors which were reported by Banu et al [81]. It is worth noting that the gas mixture content is very different between two reports.

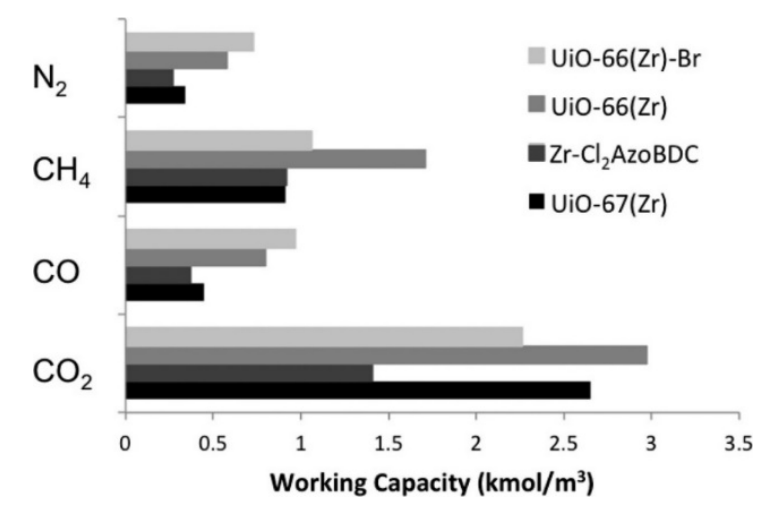

Figure 6. Working capacities from binary-mixture simulations for all impurities for a PSA operating range of 1-7 bar at $298 \mathrm{~K}$. Reprinted with permission from [81]. Copyright (2013) American Chemical Society. 

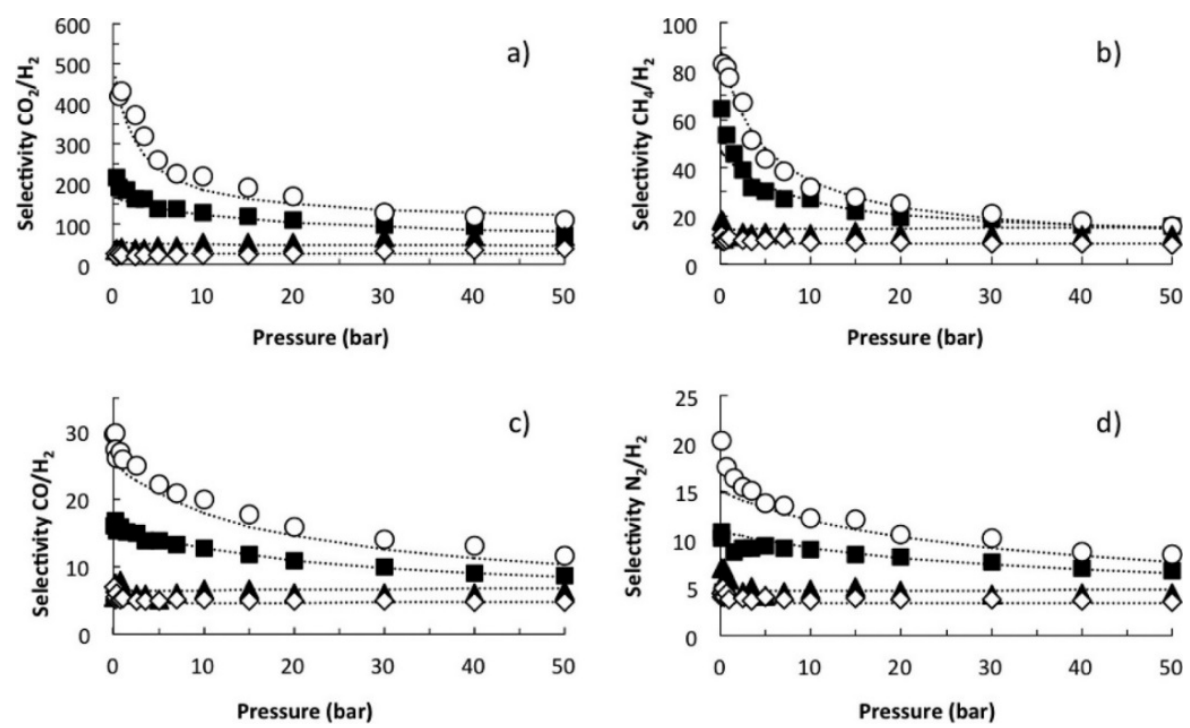

Figure 7. Selectivities from binary-mixture adsorption of (a) $\mathrm{CO}_{2} / \mathrm{H} 230: 70$, (b) $\mathrm{CH}_{4} / \mathrm{H}_{2} 30: 70$, (c) $\mathrm{CO} / \mathrm{H}_{2} 30: 70$, and (d) $\mathrm{N}_{2} / \mathrm{H}_{2} 30: 70$. UiO-67( $\mathrm{Zr}$ ), solid triangles; $\mathrm{Zr}-\mathrm{Cl}_{2} \mathrm{AzoBDC}$, open diamonds; UiO-66(Zr), solid squares; UiO-66(Zr)-Br, open spheres. The dotted lines represent the dual-site Langmuir fitted curves $\mathrm{K}$. Reprinted with permission from [81]. Copyright (2013) American Chemical Society.

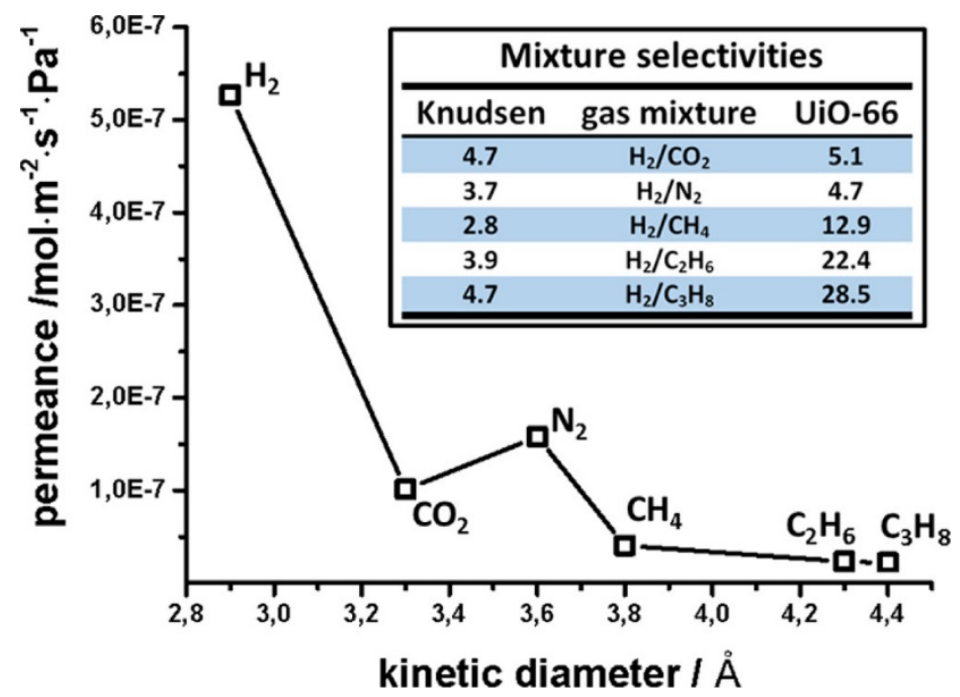

Figure 8. Gas mixture permeances for $\mathrm{CO}_{2}, \mathrm{~N}_{2}, \mathrm{CH}_{4}, \mathrm{C}_{2} \mathrm{H}_{6}$, and $\mathrm{C}_{3} \mathrm{H}_{8}$, in binary mixtures with $\mathrm{H}_{2}$ as a function of the kinetic diameter at $25^{\circ} \mathrm{C}$ and 1 bar. Inset shows the comparison between the measured mixture separation factors and the corresponding Knudsen values for the binary gas mixtures. Reprinted with permission from [82]. Copyright (2017) American Chemical Society.

\subsubsection{Other carboxylate containing MOFs}

Other MOF materials that also contain multi-carboxylate include $\mathrm{Zn}_{2}$ (cam) 2 dabco [83], Zn(BDC)(TED) 0.5 [84], CAU-1 [85], CAU-10-H [86], etc. Their permeance and selectivities for different gases are in a similar range as the carboxylate containing MFOs mentioned above and shown in table 7 . It is worth noting that CAU-10-H, which was tested in a $\mathrm{H}_{2} / \mathrm{CH}_{4}(1: 1 \mathrm{v} / \mathrm{v})$ gas mixture at $200^{\circ} \mathrm{C}$, showed a selectivity of 74.7. However, the permeance of the material was not very high $\left(1.53 \times 10^{-8} \mathrm{~mol} \mathrm{~m}^{-2} \mathrm{~s}^{-1} \mathrm{~Pa}^{-1}\right)$ and still needs improvement. More details about these materials can be found in the corresponding references.

\subsection{Zeolitic imidazolate frameworks (ZIF)}

Zeolitic imidazolate frameworks (ZIF) are one type of MOFs with similar topology to zeolites. They consist of transition metal ions (e.g. $\mathrm{Co}^{2+}$ and $\mathrm{Zn}^{2+}$ ) which are coordinated tetrahedrally by imidazolebased $(\mathrm{Im})$ ligands. Each Im ligand connects two metal ions via their nitrogen atom (see Figure 9) [87]. They are one of the most widely studied MOF materials for hydrogen separation. The main types of ZIFs that have been reported for hydrogen separation are ZIF-7, ZIF-8, ZIF-90, ZIF-94, and ZIF-95. 

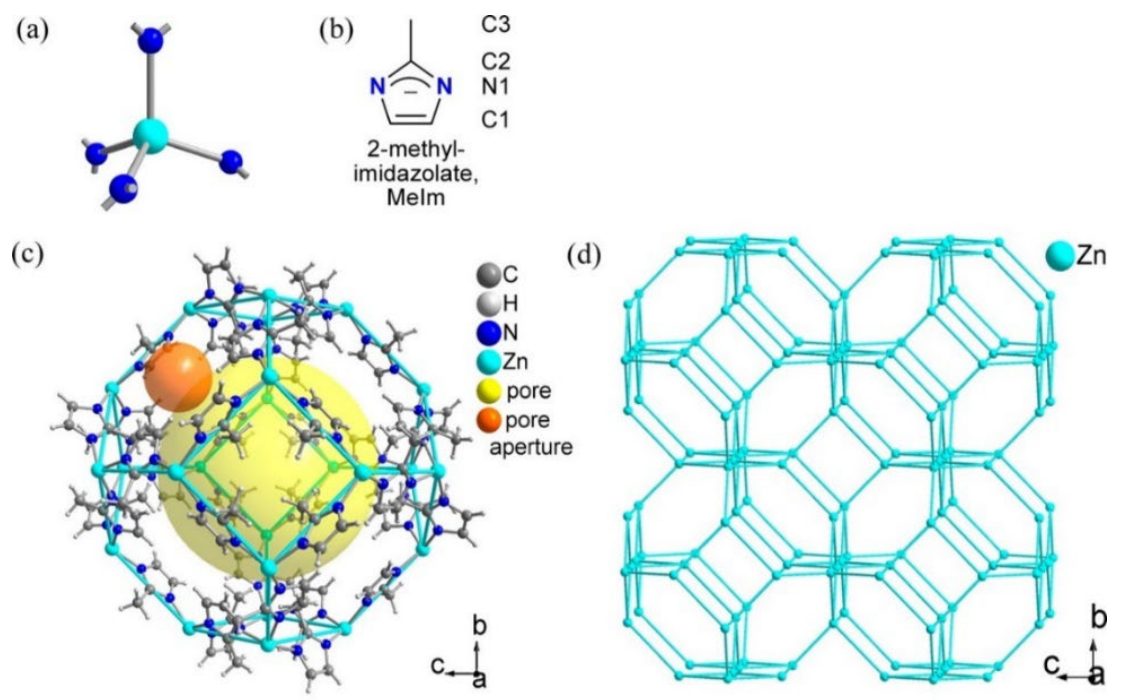

Figure 9. Structure of ZIF-8 (a) Secondary building unit of tetrahedral, nitrogen-coordinated Zn atoms and (b) bridging ligand in ZIF-8. (c) Structure of the ZIF-8 cavity, the yellow sphere with a diameter of $12 \AA$ shows the inner pore of the sodalite cage, and the orange sphere with a diameter of $3.4 \AA$ visualizes the pore aperture window of the SM hexagonal rings (d) Melm ligands bridge between Zn atoms. Reprinted with permission from [88]. Copyright (2015) American Chemical Society.

\subsubsection{ZIF-7}

As for ZIF-7, the highest $\mathrm{H}_{2}$ permeance value reported so far is $2.354 \times 10^{-6} \mathrm{~mol} \mathrm{~s}^{-1} \mathrm{~m}^{-2} \mathrm{~Pa}^{-1}$ in the form of an approximately $10 \mu \mathrm{m}$ thick membrane. The material was prepared using direct crystallization method with PVDF fibre as the support. The ideal separation factors for the corresponding material were 18.4 and 20.3 for $\mathrm{H}_{2} / \mathrm{CO}_{2}$ and $\mathrm{H}_{2} / \mathrm{N}_{2}$ respectively [89].

The highest $\mathrm{H}_{2} / \mathrm{N}_{2}(1: 1 \mathrm{v} / \mathrm{v})$ separation factor reported for ZIF-7 is 35.1 by Cacho-Bailo et al which was obtained experimentally [90]. The membrane was synthesised through direct crystallisation method with a microfluidic system. The ZIF-7 membrane is $2.4 \pm 0.4 \mu \mathrm{m}$ thick on a polysulfone hollow fibre (PSF) support. In addition, the highest experimentally obtained $\mathrm{H}_{2} / \mathrm{CH}_{4}(1: 1 \mathrm{v} / \mathrm{v})$ separation factor is also reported in the same paper (34.6). Despite its high selectivity and thin layer, the permeance of the membrane is significantly lower compared to other ZIF-7 materials that have been reported. In addition, its $\mathrm{H}_{2} / \mathrm{CO}_{2}(1: 1 \mathrm{v} / \mathrm{v})$ separation factor is 2.4 , which is significantly lower than expected [90].

The highest $\mathrm{H}_{2} / \mathrm{CO}_{2}$ separation factor for ZIF-7 material was 23.2, reported by Li et al [91]. The ZIF-7 material in this report was coupled together with reduced graphene oxide (rGO) to form a composite membrane with ZIF-7 existing between the layers of rGO. An in-situ method was used to prepare the material on a PVDF fibre support. Unfortunately, in spite of being relatively thin ( $7 \mu \mathrm{m}$ thick), this material showed very low permeance (approximately $2 \times 10^{-10} \mathrm{~mol} \mathrm{~s}^{-1} \mathrm{~m}^{-2} \mathrm{~Pa}^{-1}$ ) compared to other materials [91]. More research is needed to improve both permeance and selectivity of ZIF-7 in hydrogen purification.

\subsubsection{ZIF-8}

As an important member of MOF family, ZIF-8 is one of the most widely studied MOFs for hydrogen purification. The pore sizes of ZIF-8 (3.4 $\AA$ ) and hydrophobic behaviour are important characteristics allowing for promising performance in $\mathrm{H}_{2}$ separation applications [92].

The highest reported $\mathrm{H}_{2}$ permeance for ZIF-8 is $5.73 \times 10^{-5} \mathrm{~mol} \mathrm{~m}^{-2} \mathrm{~s}^{-1} \mathrm{~Pa}^{-1}$ with ZIF-8 being a $2 \mu \mathrm{m}$ thick membrane at room temperature. The membrane was synthesised using contra-diffusion method on an $\mathrm{Al}_{2} \mathrm{O}_{3}$ tube substrate. Its $\mathrm{H}_{2} / \mathrm{CO}_{2}$ and $\mathrm{H}_{2} / \mathrm{N}_{2}$ separation factors were 15.5 and 17.1 respectively, which are in the range of expected values for ZIF-8 [93].

The highest $\mathrm{H}_{2} / \mathrm{CO}_{2}(1: 1 \mathrm{v} / \mathrm{v})$ separation factor for ZIF-8 membrane that has been reported is 34 by Zhang et al in 2017. Its $\mathrm{H}_{2} / \mathrm{N}_{2}$ and $\mathrm{H}_{2} / \mathrm{CH}_{4}$ separation factors were 20 and 38 respectively. The membrane material was synthesised using a spatially confined contra-diffusion procedure. This involved using polydopamine-wrapped single-walled carbon nanotube (PD/SWCNT) to construct a nanoporous network as an interlayer to control the growth of ZIF-8. The ZIF-8 membrane was $0.55 \mu \mathrm{m}$ 
in thickness with a corresponding $\mathrm{H}_{2}$ permeance of only $5.75 \times 10^{-7} \mathrm{~mol} \mathrm{~m}^{-2} \mathrm{~s}^{-1} \mathrm{~Pa}^{-1}$. The relatively low permeance could be due to the small pore sizes of the PD/SWCNT interlayer, since they are in the 5$10 \mathrm{~nm}$ range. This is much smaller than other substrate materials commonly used for contra-diffusion synthesis where pore diameters are typically greater than $100 \mathrm{~nm}$ [94].

The above reasoning is supported by Hou et al, who reported a method for fast production of ZIF-8/g$\mathrm{C}_{3} \mathrm{~N}_{4}$ (graphitic carbon nitride nanosheet) membrane at room temperature [95]. This method also involved combining ZIF-8 membrane with materials of small pore sizes $\left(\mathrm{g}-\mathrm{C}_{3} \mathrm{~N}_{4}\right.$ pore size: $\left.0.31 \mathrm{~nm}\right)$. The membrane was only $0.24 \mu \mathrm{m}$ thick with a high $\mathrm{H}_{2} / \mathrm{CO}_{2}(1: 1 \mathrm{v} / \mathrm{v})$ selectivity of 26 . However, the permeance of $\mathrm{H}_{2}$ at $3.5 \times 10^{-8} \mathrm{~mol} \mathrm{~m}^{-2} \mathrm{~s}^{-1} \mathrm{~Pa}^{-1}$, was a single order lower than values reported by Zhang et al [94].

Another example supporting the above point of view is the report from Li et al. In this report, the ZIF-8 was also prepared by interfacial contra-diffusion method (see Figure 10). The interlayer material employed in this case was reduced graphene oxide (rGO) [96]. The reported pore size of graphene oxide is approximately $0.11 \mathrm{~nm}$ [97], which is even smaller than the above interlayer materials. Not surprisingly, even with a thickness of only $0.15 \mu \mathrm{m}$, the obtained material showed only slightly higher $\mathrm{H}_{2}$ permeance, approximately $6.7 \times 10^{-7} \mathrm{~mol} \mathrm{~m}^{-2} \mathrm{~s}^{-1} \mathrm{~Pa}^{-1}$, than the value in the report from Zhang et al [94]. Despite the low permeance, the material showed high separation factors for all three different binary gas mixtures (25.3 for $\mathrm{H}_{2} / \mathrm{CO}_{2}, 70.4$ for $\mathrm{H}_{2} / \mathrm{N}_{2}, 90.7$ for $\mathrm{H}_{2} / \mathrm{CH}_{4}$ ) [96]. However, it is worth noting that the ratios of gases in the gas mixture for selectivity tests were not clarified in this paper.

The highest $\mathrm{H}_{2} / \mathrm{N}_{2}(1: 1 \mathrm{v} / \mathrm{v})$ and $\mathrm{H}_{2} / \mathrm{CH}_{4}(1: 1 \mathrm{v} / \mathrm{v})$ separation factors for ZIF-8 membrane were reported to be 90.5 and 139.1 by Huang et al. The $\mathrm{H}_{2} / \mathrm{CO}_{2}(1: 1 \mathrm{v} / \mathrm{v})$ separation factor of the membrane was 14.9 and lower than the other two gas mixtures. It is also worth pointing out that the selectivity test was carried out at $250{ }^{\circ} \mathrm{C}$ [98]. In this report, ZIF-8 was prepared by depositing its precursor solution onto a modified $\mathrm{Al}_{2} \mathrm{O}_{3}$ disc. After obtaining semi-continuous $\mathrm{ZIF}-8$ crystals, graphene oxide (GO) was coated onto the surface to seal the gaps in between the crystals and to form the targeted ZIF@GO membrane (see Figure 11). The ZIF-8 membrane was $10 \mu \mathrm{m}$ in thickness with the parts filled by GO being $0.1 \mu \mathrm{m}$ in thickness. The $\mathrm{H}_{2}$ permeance of the membrane was $1.45 \times 10^{-7} \mathrm{~mol} \mathrm{~m}^{-2} \mathrm{~s}^{-1} \mathrm{~Pa}^{-1}$ and even lower for binary gas mixtures. The highest $\mathrm{H}_{2} / \mathrm{N}_{2}$ and $\mathrm{H}_{2} / \mathrm{CH}_{4}$ separation factors obtained from tests at room temperature were reported by Li et al [96].

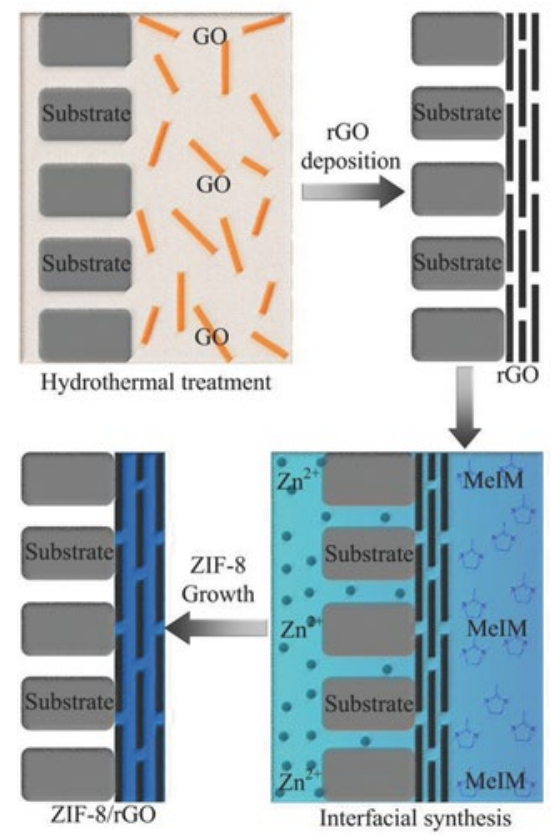

Figure 10. Schematic illustration of interfacial contra-diffusion synthesis of ZIF-8/rGO composite membranes. Reprinted from [96], Copyright (2018), with permission from John Wiley and Sons) 


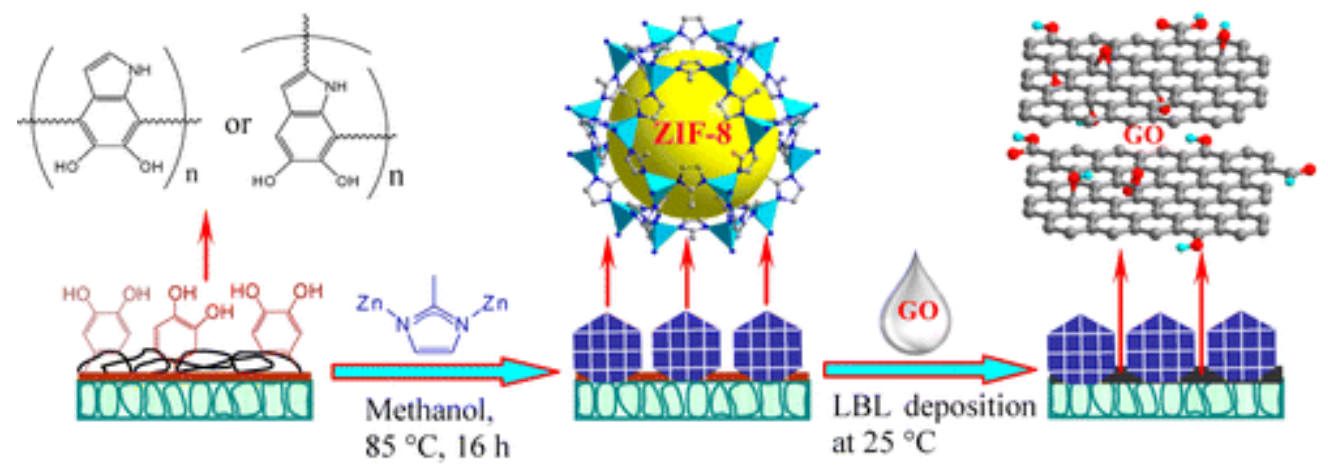

PDA-modified $\mathrm{Al}_{2} \mathrm{O}_{3} \quad$ Semi-continuous ZIF-8 layer $\quad$ ZIF-8@GO membrane

Figure 11. Schematic illustration of synthesis of bicontinuous ZIF-8@GOmembranes through layer-bylayer deposition of graphene oxide onto the semicontinuous ZIF-8 layer. Reprinted with permission from [98], Copyright (2014) American Chemical Society.

\subsubsection{ZIF-9}

Compared to ZIF-7 and ZIF-8, there is a very limited number of reports on studying ZIF-9 material for hydrogen separation. The highest hydrogen permeance $\left(1.4 \times 10^{-5} \mathrm{~mol} \mathrm{~m}^{-2} \mathrm{~s}^{-1} \mathrm{~Pa}^{-1}\right)$ for ZIF-9 membrane was reported by Zhang et al [99]. In this report, ZIF-9 existed in the form of ZIF-9-67 hybrid membrane on $\alpha-\mathrm{Al}_{2} \mathrm{O}_{3}$ support. Unfortunately, similar to other membranes with high permeance, the ideal $\mathrm{H}_{2} / \mathrm{CO}_{2}$ separation factor was not high, approximately 8.89 at room temperature. This limits the application of the material in hydrogen purification.

The highest ideal $\mathrm{H}_{2} / \mathrm{CO}_{2}$ separation factor (40.04) was reported by Huang et al in 2015 [100]. ZIF-9 membrane was synthesised via a layer-by-layer deposition method to form a CNT@IL/ZIF-9 hybrid membrane. In this method, $\mathrm{ZIF}-9$ was deposited onto $\alpha-\mathrm{Al}_{2} \mathrm{O}_{3}$ support first, before being coved by ionic liquid (IL) functionalised carbon nanotubes (CNTs). This is different from methods in other reports, which used MOF membranes to cover other functional layers instead (see Figure 10 and Figure 12) [96]. The obtained material was $30 \mu \mathrm{m}$ thick with a pore size of $4.3 \AA$. The permeance of the material was $5.45 \times 10^{-7} \mathrm{~mol} \mathrm{~m}{ }^{-2} \mathrm{~s}^{-1} \mathrm{~Pa}^{-1}$. The ideal $\mathrm{H}_{2} / \mathrm{N}_{2}$ (8.48) and $\mathrm{H}_{2} / \mathrm{CH}_{4}$ (10.35) separation factors were also studied in this report. According to the authors best knowledge, there are no other reports on $\mathrm{H}_{2} / \mathrm{N}_{2}$ and $\mathrm{H}_{2} / \mathrm{CH}_{4}$ separation factors for ZIF-9 membranes. Further research is required to gain a better understanding of the material.

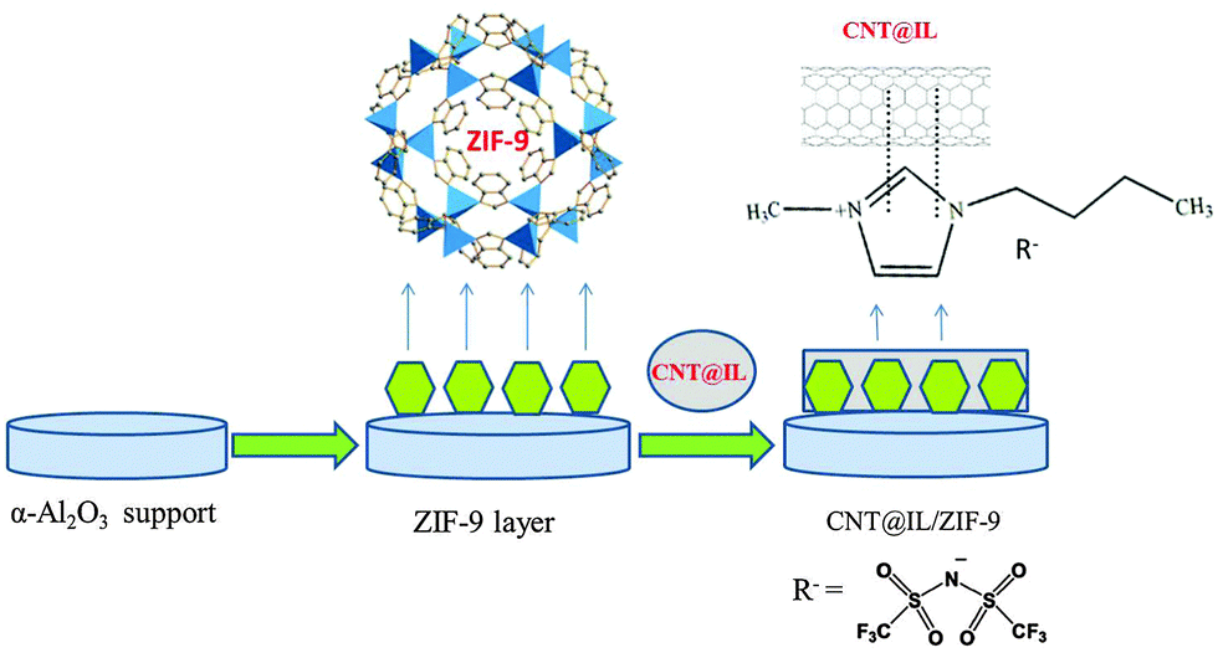

Figure 12. Schematic illustration of preparing CNT@IL/ZIF-9 hybrid membrane via heat treatment of the layer-by-layer deposition of CNT@IL on the ZIF-9 layer with an APTES modified $\alpha-\mathrm{Al}_{2} \mathrm{O}_{3}$ support [100]. Republished with permission of The Royal Society of Chemistry, Copyright 2015. 


\subsubsection{ZIF-90}

Similar to ZIF-9, the number of papers on investigating ZIF-90 membrane for hydrogen purification is very low with most of them reported by the research group of Huang et al [101-105]. The pore size of ZIF-90 is $3.5 \AA$, similar to ZIF-8. With continuous improvement, the research group managed to fabricate ZIF-90 membrane with a high $\mathrm{H}_{2} / \mathrm{CH}_{4}$ separation factor (70.5). The corresponding $\mathrm{H}_{2} / \mathrm{CO}_{2}$ separation factor was 20.1. However, its permeance was lower than expected at $2.85 \times 10^{-7}$ mol m${ }^{-2} \mathrm{~s}^{-1} \mathrm{~Pa}^{-1}$ for a $20 \mu \mathrm{m}$ thick membrane, measured at $225^{\circ} \mathrm{C}$ [103]. The $\mathrm{H}_{2} / \mathrm{N}_{2}$ separation factor of ZIF-90 was reported to be 15.8 in earlier reports by the same group. The data was also measured at a high temperature $\left(200^{\circ} \mathrm{C}\right)[101,102]$. Compared to the best performance that has been reported for ZIF-8, ZIF-90 requires further study to improve performance.

\subsubsection{Other ZIFs}

Other ZIF materials that have been investigated for hydrogen purification include ZIF-22 [106], ZIF-67 [107], ZIF-78 [108], ZIF-94 [109], ZIF-95 [110], etc the majority of which require further improvements. Among these materials, ZIF-94 showed the highest $\mathrm{H}_{2} / \mathrm{CH}_{4}$ separation factor (85.6), which was measured at $35^{\circ} \mathrm{C}$. However, the permeance of it $\left(1.6 \times 10^{-8} \mathrm{~mol} \mathrm{~m}^{-2} \mathrm{~s}^{-1} \mathrm{~Pa}^{-1}\right)$ was lower than ZIF-90, despite it being only $7.1 \mu \mathrm{m}$ thick [109]. ZIF-95 showed the highest $\mathrm{H}_{2} / \mathrm{CO}_{2}$ separation factor (25.7) at room temperature. With the thickness of $30 \mu \mathrm{m}$, the material showed permeance of $1.95 \times 10^{-6}$ $\mathrm{mol} \mathrm{m}{ }^{-2} \mathrm{~s}^{-1} \mathrm{~Pa}^{-1}[110]$. More details can be found in references 93 to 97 .

\subsection{M-bim MOFs}

Peng et al reported an exfoliation method to prepare $\mathrm{Zn}_{2}$ (benzimidazole $)_{4}\left(\mathrm{Zn}_{2}(\mathrm{bim})_{4}\right)$ molecular sieve nanosheets (MSN) from layered MOFs. This involved ball milling $\mathrm{Zn}_{2}(\mathrm{bim})_{4}$ followed by exfoliation using ultrasonication. With the thickness of $1 \mathrm{~nm}$, the MSN showed a hydrogen gas permeance of up to 9.2 $\times 10^{-7} \mathrm{~mol} \mathrm{~m}^{-2} \mathrm{~s}^{-1} \mathrm{~Pa}^{-1}$ and $\mathrm{H}_{2} / \mathrm{CO}_{2}(1: 1 \mathrm{v} / \mathrm{v})$ separation factor of over 230 . In addition, the performance of the material did not deteriorate after testing under varied conditions for over $400 \mathrm{hrs}$. When combining multiple sheets together through lamellar stacking, the performance of the material was reported to improve further [111]. However, in 2017, the same group used the same method to prepare $\mathrm{Zn}_{2}(\mathrm{bim})_{3}$ nanosheets with a thickness of $10 \mathrm{~nm}$ where a decrease in selectivity was observed. The $\mathrm{H}_{2} / \mathrm{CO}_{2}(1: 1$ $\mathrm{v} / \mathrm{v}$ ) selectivity of the material was 166 with $\mathrm{H}_{2}$ permeance of $8 \times 10^{-7} \mathrm{~mol} \mathrm{~m}^{-2} \mathrm{~s}^{-1} \mathrm{~Pa}^{-1}$ [112].

Nian et al used a vapor phase transformation method (see Figure 13) to synthesise a $57 \mathrm{~nm}$ thick $\mathrm{Co}_{2}(\mathrm{bim})_{4}$ membrane. This method involved coating $\alpha$-alumina substrate with Co-based gel before heating it in an autoclave. The autoclave contained benzimidazole (bim), which would vaporise during heating process and react with the gel to form $\mathrm{Co}_{2}(\mathrm{bim})_{4}$. The sample exhibited $\mathrm{H}_{2}$ permeance of $1.27 \times 10^{-7} \mathrm{~mol} \mathrm{~m}^{-2} \mathrm{~s}^{-1} \mathrm{~Pa}^{-1}$ at $30^{\circ} \mathrm{C}$. The corresponding $\mathrm{H}_{2} / \mathrm{CO}_{2}(1: 1 \mathrm{v} / \mathrm{v}), \mathrm{H}_{2} / \mathrm{N}_{2}(1: 1 \mathrm{v} / \mathrm{v})$, and $\mathrm{H}_{2} / \mathrm{CH}_{4}$ $(1: 1 \mathrm{v} / \mathrm{v})$ separation factors were $42.7,38.4$ and 51.3 respectively. It was also pointed out by the author that the $\mathrm{H}_{2} / \mathrm{CO}_{2}$ separation factor would increase with temperature. At $150^{\circ} \mathrm{C}$, the separation factor increased to 63 from 42.7. This was due to higher $\mathrm{H}_{2}$ permeance and unchanged $\mathrm{CO}_{2}$ permeance at high temperature [113].

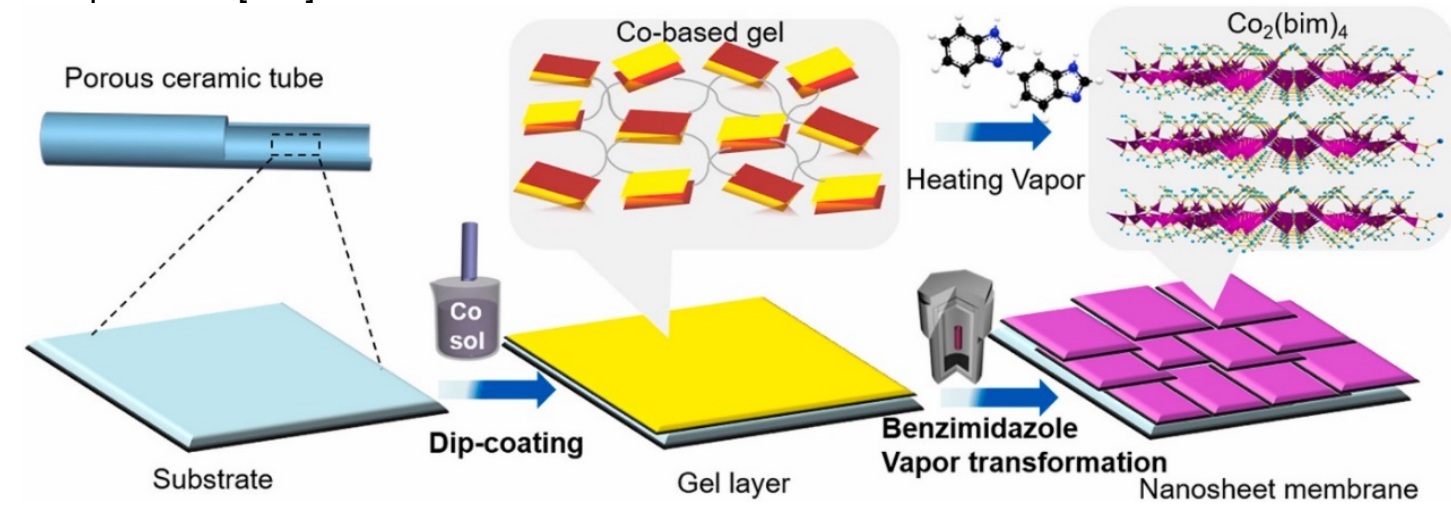

Figure 13. Schematic illustration of $\mathrm{Co}_{2}(\text { bim })_{4}$ membrane preparation via vapour phase transformation process. Reprinted from [113], Copyright (2018), with permission from Elsevier. 


\subsection{UTSA-16}

$\mathrm{K}\left(\mathrm{H}_{2} \mathrm{O}\right)_{2} \mathrm{Co}_{3}$ (cit)(Hcit)] (UTSA-16) was first reported by Xiang et al for $\mathrm{CO}_{2}$ capture [114, 115]. Using experimentally measured adsorption and diffusion data of various gases $\left(\mathrm{H}_{2}, \mathrm{~N}_{2}, \mathrm{CO}, \mathrm{CH}_{4}\right.$ and $\left.\mathrm{CO}_{2}\right)$ in the material, Agueda et al reported the performance for hydrogen purification and recovery in a simulated PSA process. With a rinse step in the PSA cycle, $99.99-99.999 \%$ pure hydrogen was generated from the process. The recovery was $93-96 \%$ with productivities ranging from 2 to 2.8 mol kg-1 $\mathrm{h}^{-1}$. The report also pointed out that the adsorption capacity of UTSA-16 for $\mathrm{CO}_{2}$ was higher than BPL activated carbon but lower than $13 \mathrm{X}$ zeolite pellets [116].

Delgado et al compared the $\mathrm{CO}_{2} / \mathrm{H}_{2}$ selectivities of CuBTC, ZIF-8, and UTSA-16 in a gas mixture of $\mathrm{CO}_{2}: \mathrm{H}_{2}=60: 40$ in a simulated PSA process. The result showed that UTSA-16 had the highest $\mathrm{CO}_{2} / \mathrm{H}_{2}$ selectivity (423) followed by CuBTC (158) and ZIF-8 (52.4). In addition, when pressure was lower than 5 bar, the sequence of $\mathrm{CO}_{2}$ adsorption capacity was UTSA-16 $>\mathrm{CuBTC}>\mathrm{ZIF}-8$. When the pressure is higher than 5 bar, the corresponding sequence became CuBTC> UTSA-16> ZIF-8 [117].

Brea et al compared the performance of MOF UTSA-16 and BPL activated carbon in PSA hydrogen purification. The volume ratio of the tested gas mixture is $\mathrm{H}_{2}: \mathrm{CO}_{2}: \mathrm{CO}: \mathrm{CH}_{4}=75.89: 17.07: 3.03$ : 4.01. The PSA beds studied in the report are (i) layered bed BPL AC/Zeolite $5 \mathrm{~A}$ and (ii) layered bed UTSA-16/Zeolite 5A. MOF UTSA-16 showed a lower adsorption capacity and recovery than activated carbon. The author attributed the lower performance of UTSA-16 to its higher isotherm curvature for $\mathrm{CO}_{2}$, lower working capacities of $\mathrm{CO}$ and $\mathrm{CH}_{4}$, etc. [118].

\subsection{COF-MOF}

COF (covalent-organic framework)-MOF composite membrane for hydrogen purification was first reported by $\mathrm{Fu}$ et al. In this report, the MOF materials $\left(\mathrm{Zn}_{2}(\mathrm{bdc})_{2}(\right.$ dabco $)$ and $\left.\mathrm{ZIF}-8\right)$ were grown on chemically modified $\mathrm{SiO}_{2}$ disks which were already covered with COF-300. The thickness of the obtained membranes is shown below:

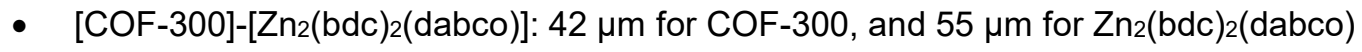

- [COF-300]-[ZIF-8]: $40 \mu \mathrm{m}$ for COF-300, and $60 \mu \mathrm{m}$ for ZIF-8

[COF-300]-[Zn 2 (bdc) 2 (dabco)] showed $\mathrm{H}_{2}$ permeance of $4.6 \times 10^{-7} \mathrm{~mol} \mathrm{~m}^{-2} \mathrm{~s}^{-1} \mathrm{~Pa}^{-1}$ with $\mathrm{H}_{2} / \mathrm{CO}_{2}(1: 1 \mathrm{v} / \mathrm{v})$ separation factor of 12.6. [COF-300]-[ZIF-8] showed $\mathrm{H}_{2}$ permeance of the $3.6 \times 10^{-7} \mathrm{~mol} \mathrm{~m}^{-2} \mathrm{~s}^{-1} \mathrm{~Pa}^{-1}$ with $\mathrm{H}_{2} / \mathrm{CO}_{2}(1: 1 \mathrm{v} / \mathrm{v})$ separation factor of 17.2 [119].

Saikat et al grew UiO-66 on $\mathrm{SiO}_{2}$ disks first followed by growing COF-300 on top of UiO-66. In the [COF300]-[UiO-66] composite membrane, COF-300 was $60 \mu \mathrm{m}$ thick and UiO-66 was $40 \mu \mathrm{m}$ thick. This material showed a higher $\mathrm{H}_{2} / \mathrm{CO}_{2}(1: 1 \mathrm{v} / \mathrm{v})$ separation factor (17.2) than the above two materials. The permeance of the sample $\left(3.8 \times 10^{-7} \mathrm{~mol} \mathrm{~m}^{-2} \mathrm{~s}^{-1} \mathrm{~Pa}^{-1}\right)$ was, however, lower than the other two materials [120].

\subsection{MOFs tested for $\mathrm{CO}$ adsorption}

Most MOF materials reported for hydrogen purification focus on impurities such as $\mathrm{CO}_{2}, \mathrm{~N}_{2}, \mathrm{CH}_{4}$, and other hydrocarbons. A limited number of papers reported the performance of MOFs in removing $\mathrm{CO}$ from hydrogen. These papers are summarized below.

Fischer et al used Monte Carlo simulations to compare the $\mathrm{CO} / \mathrm{H}_{2}$ selectivity and working capacity of five different materials (zeolite: silicalite; MOFs: Mg-formate, $\mathrm{Zn}(\mathrm{dtp}), \mathrm{Cu}_{3}(\mathrm{BTC})_{2}$; porous molecular crystal: cucurbit[6]uril). Despite $\mathrm{Cu}_{3}(\mathrm{BTC})_{2}$ exhibited the highest working capacity, it also showed the lowest selectivity (lower than BPL activated carbon) caused by its large pores. However, all the other materials showed higher selectivity than BPL activated carbon whose Henry's law selectivity is $\alpha=12.8$. It was highlighted that Mg-formate maintained a high selectivity of $\alpha>30$ under all evaluated pressures. The authors concluded that materials with narrow channels showed the best performance in purifying hydrogen due to maximized dispersive interactions. In addition, polar materials have stronger electrostatic interactions with $\mathrm{CO}$, which are preferred in $\mathrm{CO} / \mathrm{H}_{2}$ separation [121].

After obtaining single gas adsorption isotherm data, Wu et al used IAST to evaluate the selectivities of a rht-type metal-organic framework [ $\left.\mathrm{Cu}_{3}(\mathrm{TDPAT})\left(\mathrm{H}_{2} \mathrm{O}\right)_{3}\right] \cdot 10 \mathrm{H}_{2} \mathrm{O} \cdot 5 \mathrm{DMA}$ (Cu-TDPAT). The gas mixtures investigated in this report were $\mathrm{CO}_{2} / \mathrm{CO} / \mathrm{CH}_{4} / \mathrm{H}_{2}, \mathrm{CO}_{2} / \mathrm{H}_{2}, \mathrm{CH}_{4} / \mathrm{H}_{2}$, and $\mathrm{CO}_{2} / \mathrm{CH}_{4}$ at pressures up to 70 bar. By comparing the results with other materials (Mg-MOF-74, MIL-101, LTA-5A, and NaX), it was found that the $\mathrm{CO}_{2} / \mathrm{H}_{2}$ selectivity of Cu-TDPAT was better than MIL-101, but lower than the others (see 
Figure 14). However, the productivity of Cu-TDPAT was higher than more commonly used NaX zeolite when pressures were higher than 20 bar (see Figure 15) [122].
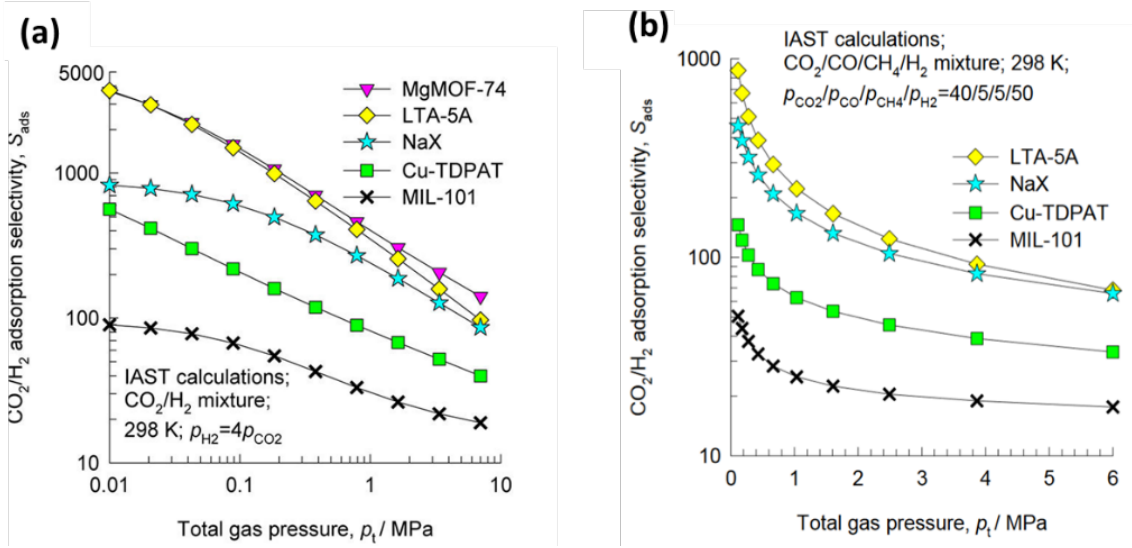

Figure 14. IAST calculations for $\mathrm{CO}_{2} / \mathrm{H}_{2}$ selectivity (a) $\mathrm{CO}_{2} / \mathrm{H}_{2}=20 / 80$, (b) $\mathrm{CO}_{2} / \mathrm{CO} / \mathrm{CH}_{4} / \mathrm{H}_{2}=40 / 5 / 5 / 50$. Reprinted with permission from [122], Copyright (2012) American Chemical Society.

Yin et al incorporated ZIF-8 based membrane into a membrane reactor to improve the CO conversion efficiency and the $\mathrm{H}_{2}$ purity in low-temperature water gas shift reactions. According to their single gas permeation tests at room temperature, the $1 \mu \mathrm{m}$ thick $\mathrm{ZIF}-8$ membrane showed $\mathrm{H}_{2}, \mathrm{CO}$ and $\mathrm{CO}_{2}$ permeances of $9.2 \times 10^{-7} \mathrm{~mol} \mathrm{~m}^{-2} \mathrm{~s}^{-1} \mathrm{~Pa}^{-1}, 1.5 \times 10^{-7} \mathrm{~mol} \mathrm{~m}^{-2} \mathrm{~s}^{-1} \mathrm{~Pa}^{-1}$, and $2.3 \times 10^{-7} \mathrm{~mol} \mathrm{~m}^{-2} \mathrm{~s}^{-1} \mathrm{~Pa}^{-1}$ respectively. Therefore, the corresponding ideal $\mathrm{H}_{2} / \mathrm{CO}$ and $\mathrm{H}_{2} / \mathrm{CO}_{2}$ separation factors were 6.13 and 4.00. Apart from single gas tests, the group also tested gas separation performance of the membrane for mixed gases $\left(\mathrm{H}_{2}\right.$ : $\left.\mathrm{CO}: \mathrm{CO}_{2}=2: 1: 1\right)$. The resulting permeances of different gases were $6.2 \times 10^{-7}$ $\mathrm{mol} \mathrm{m}^{-2} \mathrm{~s}^{-1} \mathrm{~Pa}^{-1}\left(\mathrm{H}_{2}\right), \quad 1.2 \times 10^{-7} \mathrm{~mol} \mathrm{~m}^{-2} \mathrm{~s}^{-1} \mathrm{~Pa}^{-1} \quad(\mathrm{CO})$, and $1.8 \times 10^{-7} \mathrm{~mol} \mathrm{~m}^{-2} \mathrm{~s}^{-1} \mathrm{~Pa}^{-1} \quad\left(\mathrm{CO}_{2}\right)$. The obtained $\mathrm{H}_{2} / \mathrm{CO}$ and $\mathrm{H}_{2} / \mathrm{CO}_{2}$ separation factors were 4.92 and 3.18 respectively [123].

(a)

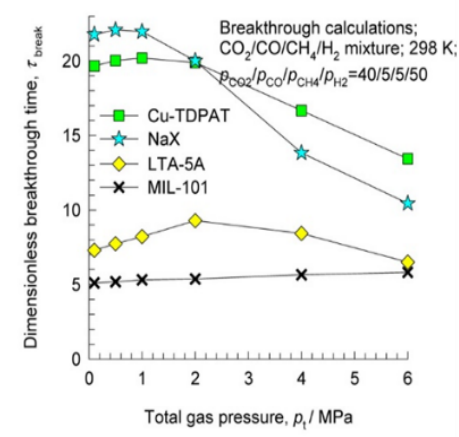

(b)

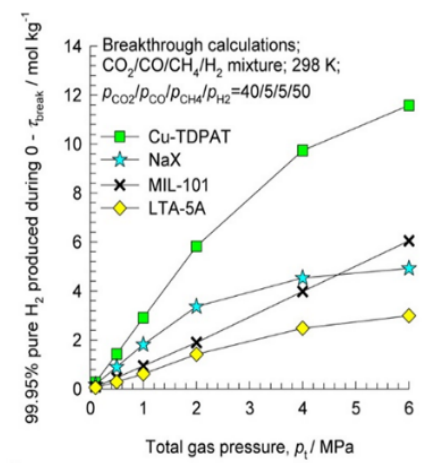

(c)

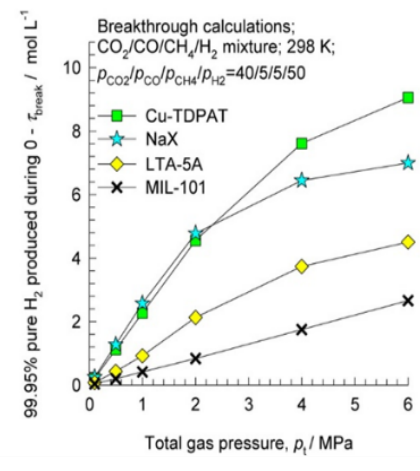

Figure 15. Influence of the total operating pressure on (a) dimensionless breakthrough times and the number of moles of $99.95 \%+$ pure $\mathrm{H}_{2}$ produced (b) per $\mathrm{kg}$ of adsorbent material and (c) per $L$ of adsorbent material during the time interval 0-Tbreak. The breakthrough times, Tbreak, correspond to those when the outlet gas contains $500 \mathrm{ppm}\left(\mathrm{CO}_{2}+\mathrm{CO}+\mathrm{CH}_{4}\right)$. Reprinted with permission from [122], Copyright (2012) American Chemical Society.

\subsection{Other MOFs}

Other MOF materials that have been reported for hydrogen separation (i.e. $\mathrm{Zn}_{2}(\mathrm{cam})_{2}$ dabco [83], $\mathrm{Cu}$ (hfipbb)( $\mathrm{H}_{2}$ hfipbb) 0.5 [124] , $\mathrm{Cu}_{2}(\text { bza })_{4}(\mathrm{pyz})$ [125] , Ni-(4-pyridylcarboxylate) ${ }_{2}$ [126]) can be found in the references. Ni-(4-pyridylcarboxylate $)_{2}$ is highlighted here due to its high $\mathrm{CO}_{2} / \mathrm{H}_{2}$ selectivities.

Nandi et al synthesised a single-ligand Ni-(4-pyridylcarboxylate) ${ }_{2}$ (Ni-4PyC) MOF material which had ultra-micro porosities of 3.5 and $4.8 \AA$ and a surface area of $945 \mathrm{~m}^{2} / \mathrm{g}$. At $10 \mathrm{bar}, 40^{\circ} \mathrm{C}$, the material showed $\mathrm{CO}_{2} / \mathrm{H}_{2}$ selectivities of 285 for $\mathrm{CO}_{2}: \mathrm{H}_{2}=20: 80$ gas mixture and 230 for $\mathrm{CO}_{2}: \mathrm{H}_{2}=40: 60$ gas mixture. The working capacity of the material was found to be $3.95 \mathrm{mmol} / \mathrm{g}$. In addition, Ni-4PyC was able to remain stable after steam treatment of $160 \mathrm{hrs}$ and presentation under pressure of 70 bar for 24 
hrs. Its resistance to humidity during adsorption also made it a very attractive candidate for hydrogen purification [126].

\section{Conclusion and outlook}

In this review, we have summarised MOFs materials that have been reported for hydrogen purification with a focus on MOFs separating $\mathrm{H}_{2}$ from the common impurity gases such as $\mathrm{CO}_{2}, \mathrm{CH}_{4}$, and $\mathrm{N}_{2}$. Their performance in separating the above impurity gases have been compared systematically to identify high performing materials and to provide reference points for comparing research results for researchers in this area.

- The highest $\mathrm{H}_{2}$ permeance of MOFs that has been reported so far is CuBTC $\left(7.05 \times 10^{-5}\right.$ mol m $\mathrm{m}^{-2} \mathrm{~s}^{-1} \mathrm{~Pa}^{-1}$ ). However, the selectivities of the material are insufficient [69].

- The MOF material showing the highest overall selectivity is CuBTC/MIL-100: 77.6 for $\mathrm{H}_{2} / \mathrm{CO}_{2}$, 217.0 for $\mathrm{H}_{2} / \mathrm{N}_{2}$, and 335.7 for $\mathrm{H}_{2} / \mathrm{CH}_{4}$. Unfortunately, the permeance of the material is not high enough $\left(8.8 \times 10^{-8} \mathrm{~mol} \mathrm{~m}^{-2} \mathrm{~s}^{-1} \mathrm{~Pa}^{-1}\right)[68]$.

- For commercial applications, MOF materials should possess both high permeance and high selectivities. The most promising material seems to be ZIF-8 reported by Li et al. This material exhibited a balance between permeance and selectivity with a permeance of $6.7 \times 10^{-7} \mathrm{~mol}$ $\mathrm{m}^{-2} \mathrm{~s}^{-1} \mathrm{~Pa}^{-1}$ and separation factors of 25.3 for $\mathrm{H}_{2} / \mathrm{CO}_{2}, 70.4$ for $\mathrm{H}_{2} / \mathrm{N}_{2}, 90.7$ for $\mathrm{H}_{2} / \mathrm{CH}_{4}$ [96]. The ratios of components in the gas mixture were not mentioned in this report nor in the study on $\mathrm{CuBTC/MIL-100}$. Therefore, it is difficult to comment further on the relative performance of the material.

During the review process, research gaps have also been identified and more research could be carried out in the following area in the future:

- There are very few reports on the performance of MOFs in separating hydrogen from $\mathrm{CO}$, which is one of the major impurities in industrial hydrogen and cause more severe damage to fuel cell performance than the other impurity gases. More research should be focused in this area.

- Most reports focus on testing the performance of MOF materials in separating hydrogen in binary gas mixtures. The number of reports of MOF materials separating hydrogen from more than one contaminant gas is very limited. Due to competitive adsorption and desorption of various gases on adsorbents, the separation factors obtained from mixed gas tests can be lower than the values obtained from binary gas tests or single gas tests. Therefore, it is important to focus further research in these areas to provide more reliable data for practical applications.

- The mechanical strength and structural stability of MOFs could be improved, as they are lower than other materials such as zeolites. This is important especially when they are working with feed gases containing aggressive components, under high pressures or made into thin membranes for hydrogen purification.

- The hydrothermal stability of MOFs at high temperatures could be improved if they were to be used to purify hydrogen generated from the water gas shift reaction process as the gas temperature from this process can be very high.

- There is limited understanding of the gas separation mechanisms which occur when using MOF membranes. Developing a better understanding could help identify factors that lead to high performance in MOF materials and help other researchers to tailor their materials to achieve better performance.

- Gas permeance and selectivities of MOFs could be further improved for industrial application.

- The cost of synthesising MOF materials is still very high for commercial applications compared to other traditional materials e.g. the price of a commercial CuBTC is 126 times of $5 \mathrm{~A}$ zeolites. Although this could be helped by large scale production, MOFs can be very sensitive synthesis conditions. Therefore, it is also important to check the reproducibility of the synthesis method. 
Table 7. Summary of MOF materials for $\mathrm{H}_{2}$ separation (Adapted from Ref [46] with the permission from the Royal Society of Chemistry; Reprinted from Progress in Materials Science, Vol 100, Li W. Metal-organic framework membranes: Production, modification, and applications, Pages 21-63, Copyright (2018), with permission from Elsevier [47])

a:The data was obtained from the single-component permeation. RT: room temperature.

\begin{tabular}{|c|c|c|c|c|c|c|c|c|c|c|c|c|}
\hline MOF & $\begin{array}{l}\text { Substr } \\
\text { ate }\end{array}$ & Method & $\begin{array}{l}\text { Solvent | } \\
\text { Component }\end{array}$ & \multirow[t]{4}{*}{$\begin{array}{l}\text { Por } \\
\text { e } \\
\text { size } \\
\text { (A) } \\
15.6\end{array}$} & $\begin{array}{l}\text { Thicknes } \\
\mathrm{s}(\mu \mathrm{m})\end{array}$ & $\begin{array}{l}\text { Permeanc } \\
\text { e Tem } \\
\left({ }^{\circ} \mathrm{C}\right)\end{array}$ & Gas pair & $\begin{array}{l}\text { Permea } \\
\left(\times 10^{-8} \mathrm{n}\right. \\
\text { Before }\end{array}$ & $\begin{array}{l}\left.\text { ol }{ }^{-1} \mathrm{~m}^{-2} \mathrm{~Pa}^{-1}\right) \\
\text { After }\end{array}$ & $\begin{array}{l}\text { Selec } \\
\text { Befo } \\
\text { re }\end{array}$ & $\begin{array}{l}\text { ivity } \\
\text { After }\end{array}$ & Ref. \\
\hline \multirow[t]{3}{*}{ MOF-5 } & $\alpha-\mathrm{Al}_{2} \mathrm{O}_{3}$ & Dip-coating & DMF & & 40 & RT & $\mathrm{H}_{2} / \mathrm{CO}_{2}$ & 80 & & 2.5 & & [63] \\
\hline & & & & & & & $\mathrm{H}_{2} / \mathrm{N}_{2}$ & & & 2.7 & & \\
\hline & & & & & & & $\mathrm{H}_{2} / \mathrm{CH}_{4}$ & & & 2 & & \\
\hline \multirow[t]{2}{*}{ MOF-5 } & $\begin{array}{l}\alpha-\mathrm{Al}_{2} \mathrm{O}_{3} \\
\text { disks }\end{array}$ & Coating & EtOH/water & 8 & 14 & RT & $\mathrm{H}_{2} / \mathrm{CO}_{2}$ & 43 & & $4 \underline{a}$ & & [64] \\
\hline & & & & & & & $\mathrm{H}_{2} / \mathrm{N}_{2}$ & & & $4.1 \underline{a}$ & & \\
\hline MIL-53 (Al) & $\begin{array}{l}\alpha-\mathrm{Al}_{2} \mathrm{O}_{3} \\
\text { disks }\end{array}$ & Embedding & $\mathrm{Al}\left(\mathrm{NO}_{3}\right)_{3} \cdot 9 \mathrm{H}_{2} \mathrm{O}$ & $\begin{array}{l}7.3 \\
\times \\
7.7\end{array}$ & 8 & RT & $\begin{array}{l}\mathrm{H}_{2} / \mathrm{CO}_{2} \\
\mathrm{H}_{2} / \mathrm{N}_{2} \\
\mathrm{H}_{2} / \mathrm{CH}_{4}\end{array}$ & 50 & & $\begin{array}{l}4^{a} \\
2.5^{a} \\
2.2^{a}\end{array}$ & & [127] \\
\hline $\mathrm{NH}_{2}-\mathrm{MIL}-53(\mathrm{Al})$ & $\begin{array}{l}\text { Porous } \\
\mathrm{SiO}_{2}\end{array}$ & Deposition & DMF & 7.5 & 15 & $15-80$ & $\begin{array}{l}\mathrm{H}_{2} / \mathrm{CO}_{2} \\
\mathrm{H}_{2} / \mathrm{N}_{2} \\
\mathrm{H}_{2} / \mathrm{CH}_{4}\end{array}$ & 200 & & $\begin{array}{l}30.9 \\
23.9 \\
20.7\end{array}$ & & [128] \\
\hline \multirow[t]{2}{*}{$\mathrm{NH}_{2}-\mathrm{MIL}-53$} & $\begin{array}{l}\text { PVDF } \\
\text { fiber }\end{array}$ & $\begin{array}{l}\text { Direct } \\
\text { crystallization }\end{array}$ & DMF & 7.5 & 8 & RT & $\begin{array}{l}\mathrm{H}_{2} / \mathrm{CO}_{2} \\
\mathrm{H}_{2} / \mathrm{N}_{2}\end{array}$ & $\begin{array}{l}421 \\
542^{\mathrm{a}}\end{array}$ & & $\begin{array}{l}32.4 \\
27.9 \mathrm{a}\end{array}$ & & [67] \\
\hline & & & & & & & $\mathrm{H}_{2} / \mathrm{CH}_{4}$ & & & $27.3^{a}$ & & \\
\hline MIL-100 & $\begin{array}{l}\text { PVDF } \\
\text { fiber }\end{array}$ & Embedding & rGO & - & 7.5 & RT & $\mathrm{H}_{2} / \mathrm{CO}_{2}$ & - & 1.3 & - & 12.5 & [91] \\
\hline CuBTC/MIL-100 & $\begin{array}{l}\text { PVDF } \\
\text { fiber }\end{array}$ & Substitution & $\mathrm{FeCl}_{3} \cdot 6 \mathrm{H}_{2} \mathrm{O}$ & $\begin{array}{l}3.5 \\
5,9\end{array}$ & 20 & 25 & $\begin{array}{l}\mathrm{H}_{2} / \mathrm{CO}_{2} \\
\mathrm{H}_{2} / \mathrm{N}_{2} \\
\mathrm{H}_{2} / \mathrm{CH}_{4}\end{array}$ & 201a & 7.4 & $\begin{array}{l}6.4^{\mathrm{a}} \\
6.2^{\mathrm{a}} \\
6.2^{\mathrm{a}}\end{array}$ & $\begin{array}{l}77.6 \\
217.0 \\
335.7\end{array}$ & [68] \\
\hline CuBTC & $\begin{array}{l}\text { Copper } \\
\text { net }\end{array}$ & $\begin{array}{l}\text { Twin copper } \\
\text { source }\end{array}$ & $\mathrm{EtOH} /$ Water & 7.8 & 60 & RT & $\begin{array}{l}\mathrm{H}_{2} / \mathrm{CO}_{2} \\
\mathrm{H}_{2} / \mathrm{N}_{2} \\
\mathrm{H}_{2} / \mathrm{CH}_{4}\end{array}$ & 150 & & $\begin{array}{l}6.8 \\
7 \\
5.9\end{array}$ & & [129] \\
\hline CuBTC & $\begin{array}{l}\mathrm{a}-\mathrm{Al}_{2} \mathrm{O}_{3} \\
\text { disks }\end{array}$ & $\begin{array}{l}\text { Step-by-step } \\
\text { deposition }\end{array}$ & Water & 9 & 25 & RT & $\begin{array}{l}\mathrm{H}_{2} / \mathrm{CO}_{2} \\
\mathrm{H}_{2} / \mathrm{N}_{2} \\
\mathrm{H}_{2} / \mathrm{CH}_{4}\end{array}$ & $40-60$ & & $\begin{array}{l}4.6 \\
3.7 \\
3\end{array}$ & & [130] \\
\hline CuBTC & $\begin{array}{l}\alpha-\mathrm{Al}_{2} \mathrm{O}_{3} \\
\text { tube }\end{array}$ & Dip-coating & $\mathrm{EtOH} /$ Water & 9 & 13 & RT & $\begin{array}{l}\mathrm{H}_{2} / \mathrm{CO}_{2} \\
\mathrm{H}_{2} / \mathrm{N}_{2}\end{array}$ & 4.1 & & $\begin{array}{l}13.6 \\
6.8\end{array}$ & & [70] \\
\hline
\end{tabular}




\begin{tabular}{|c|c|c|c|c|c|c|c|c|c|c|c|c|}
\hline \multirow[t]{2}{*}{ MOF } & \multirow{2}{*}{$\begin{array}{l}\text { Substr } \\
\text { ate }\end{array}$} & \multirow[t]{2}{*}{ Method } & \multirow{2}{*}{$\begin{array}{l}\text { Solvent | } \\
\text { Component }\end{array}$} & \multirow{3}{*}{$\begin{array}{l}\text { Por } \\
\text { e } \\
\text { size } \\
(\AA) \\
9\end{array}$} & \multirow{2}{*}{$\begin{array}{l}\text { Thicknes } \\
\mathrm{s}(\mu \mathrm{m})\end{array}$} & \multirow{2}{*}{$\begin{array}{l}\text { Permeanc } \\
\text { e Tem } \\
\left({ }^{\circ} \mathrm{C}\right)\end{array}$} & \multirow[t]{2}{*}{ Gas pair } & \multicolumn{2}{|c|}{$\begin{array}{l}\text { Permeance } \\
\left(\times 10^{-8} \mathrm{~mol} \mathrm{~s}^{-1} \mathrm{~m}^{-2} \mathrm{~Pa}^{-1}\right)\end{array}$} & \multicolumn{2}{|c|}{ Selectivity } & \multirow[t]{2}{*}{ Ref. } \\
\hline & & & & & & & & Before & After & $\begin{array}{l}\text { Befo } \\
\text { re }\end{array}$ & After & \\
\hline CuBTC & $\begin{array}{l}\text { Porous } \\
\mathrm{SiO}_{2} \\
\text { metal } \\
\text { nets }\end{array}$ & Coating & EtOH/Water & & - & 25 & $\begin{array}{l}\mathrm{H}_{2} / \mathrm{CO}_{2} \\
\mathrm{H}_{2} / \mathrm{N}_{2} \\
\mathrm{H}_{2} / \mathrm{CH}_{4}\end{array}$ & 129 & & $\begin{array}{l}9.24 \\
8.91 \\
11.2\end{array}$ & & [72] \\
\hline CuBTC & Non & $\begin{array}{l}\text { Confinement } \\
\text { conversion }\end{array}$ & EtOH/Water & 9 & 5.0 & RT & $\begin{array}{l}\mathrm{H}_{2} / \mathrm{CO}_{2} \\
\mathrm{H}_{2} / \mathrm{N}_{2} \\
\mathrm{H}_{2} / \mathrm{CH}_{4}\end{array}$ & $158^{a}$ & & $\begin{array}{l}6.1 \\
5.0 \\
4.0\end{array}$ & & [131] \\
\hline CuBTC & $\begin{array}{l}\text { PSF } \\
\text { flat }\end{array}$ & Layer by layer & $\begin{array}{l}\mathrm{DMF} / \mathrm{EtOH} / \mathrm{H}_{2} \mathrm{O} \\
- \\
\mathrm{DMF} / \mathrm{EtOH} / \mathrm{H}_{2} \mathrm{O}\end{array}$ & $5-9$ & 25 & RT & $\begin{array}{l}\mathrm{H}_{2} / \mathrm{CO}_{2} \\
\mathrm{H}_{2} / \mathrm{C}_{3} \mathrm{H}_{6}\end{array}$ & $7.9 \underline{a}$ & & $\begin{array}{l}7.2^{\mathrm{a}} \\
5.7^{\mathrm{a}}\end{array}$ & & [132] \\
\hline CuBTC & $\begin{array}{l}\mathrm{Al}_{2} \mathrm{O}_{3} \\
\text { disc }\end{array}$ & $\begin{array}{l}\text { Rapid thermal } \\
\text { deposition }\end{array}$ & DMF & - & $20-25$ & RT & $\begin{array}{l}\mathrm{H}_{2} / \mathrm{N}_{2} \\
\mathrm{H}_{2} / \mathrm{CH}_{4}\end{array}$ & 30 & & $\begin{array}{l}13.7^{\mathrm{a}} \underline{\mathrm{a}} \\
8.8^{\mathrm{a}}\end{array}$ & & [71] \\
\hline CuBTC & $\begin{array}{l}\text { PAN } \\
\text { fiber }\end{array}$ & $\begin{array}{l}\text { Direct } \\
\text { crystallization }\end{array}$ & Water/EtOH & 9 & 13 & 20 & $\mathrm{H}_{2} / \mathrm{CO}_{2}$ & 7050.0 & & 7.1 & & [69] \\
\hline CuBTC & $\begin{array}{l}\text { PVDF } \\
\text { fiber }\end{array}$ & $\begin{array}{l}\text { Confinement } \\
\text { conversion }\end{array}$ & EtOH/Water & 9 & 3.0 & RT & $\begin{array}{l}\mathrm{H}_{2} / \mathrm{CO}_{2} \\
\mathrm{H}_{2} / \mathrm{N}_{2} \\
\mathrm{H}_{2} / \mathrm{CH}_{4}\end{array}$ & 201 & & $\begin{array}{l}8.1 \\
6.5 \\
5.4\end{array}$ & & [133] \\
\hline CuBTC & $\begin{array}{l}\text { PVDF } \\
\text { fiber }\end{array}$ & $\begin{array}{l}\text { Direct } \\
\text { crystallization }\end{array}$ & Water/EtOH & - & 43 & RT & $\begin{array}{l}\mathrm{H}_{2} / \mathrm{CO}_{2} \\
\mathrm{H}_{2} / \mathrm{N}_{2}\end{array}$ & $\begin{array}{l}601.2 \\
846.0\end{array}$ & & $\begin{array}{l}7.91 \\
5.87 \underline{a}\end{array}$ & & [134] \\
\hline CuBTC & $\begin{array}{l}\text { PVDF } \\
\text { fiber }\end{array}$ & Embedding & rGO & 10 & 8 & RT & $\mathrm{H}_{2} / \mathrm{CO}_{2}$ & - & 88 & - & 10.0 & [91] \\
\hline CuBTC & $\begin{array}{l}\mathrm{Al}_{2} \mathrm{O}_{3} \\
\text { disc }\end{array}$ & $\begin{array}{l}\text { Spray/Layer by } \\
\text { layer }\end{array}$ & EtOH-EtOH & - & 0.5 & RT & $\mathrm{H}_{2} / \mathrm{CO}_{2}$ & 3 & & 8.5 & & [135] \\
\hline \multirow[t]{3}{*}{ Ni-MOF-74 } & $\mathrm{a}-\mathrm{Al}_{2} \mathrm{O}_{3}$ & Layer-by-layer & THF+DI & 11 & 25 & RT & $\mathrm{H}_{2} / \mathrm{CO}_{2}$ & 1000 & & 9.1 & & [79] \\
\hline & & & & & & & $\mathrm{H}_{2} / \mathrm{N}_{2}$ & & & 3.1 & & \\
\hline & & & & & & & $\mathrm{H}_{2} / \mathrm{CH}_{4}$ & & & 2.9 & & \\
\hline Mg-MOF-74 & $\begin{array}{l}\mathrm{Al}_{2} \mathrm{O}_{3} \\
\text { disc }\end{array}$ & Grafting & EDA & 11 & 10 & 25 & $\mathrm{H}_{2} / \mathrm{CO}_{2}$ & 12 & 8.2 & 10.5 & 28 & [74] \\
\hline \multirow[t]{3}{*}{ UiO-66 } & $\alpha-\mathrm{Al}_{2} \mathrm{O}_{3}$ & Hydrothermal & DMF & 6 & 5 & RT & $\mathrm{H}_{2} / \mathrm{CO}_{2}$ & 53 & & 5.1 & & [82] \\
\hline & & & & & & & $\mathrm{H}_{2} / \mathrm{N}_{2}$ & & & 4.7 & & \\
\hline & & & & & & & $\mathrm{H}_{2} / \mathrm{CH}_{4}$ & & & 12.9 & & \\
\hline $\begin{array}{l}\mathrm{Zn}(\mathrm{BDC})(\mathrm{TED})_{0 .} . \\
5\end{array}$ & $\begin{array}{l}\alpha-\mathrm{Al}_{2} \mathrm{O}_{3} \\
\text { disk }\end{array}$ & $\begin{array}{l}\text { Direct } \\
\text { crystallization }\end{array}$ & $\mathrm{EtOH}$ & 7.5 & 25 & RT & $\mathrm{H}_{2} / \mathrm{CO}_{2}$ & 270 & & 12.1 & & [84] \\
\hline
\end{tabular}




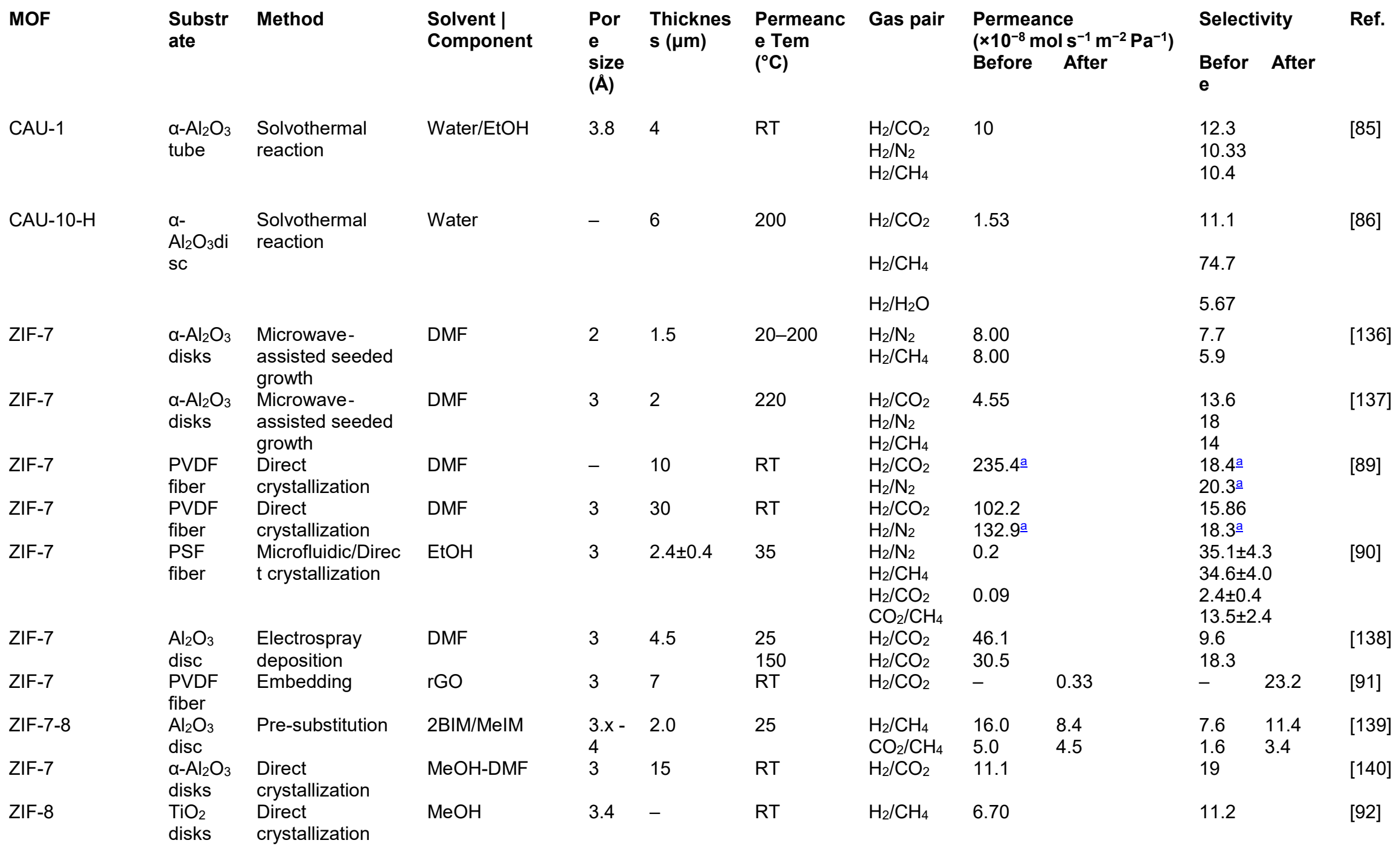


$\left({ }^{\circ} \mathrm{C}\right)$

Before $\mathrm{m}^{-2} \mathrm{~Pa}^{-1}$

Befor After

10.3

$\mathrm{H}_{2} / \mathrm{N}_{2} \quad 20$

$\mathrm{H}_{2} / \mathrm{CH}_{4}$

$\mathrm{H}_{2} / \mathrm{N}_{2} \quad 17$

11.6

$\mathrm{H}_{2} / \mathrm{CH}_{4}$

disks crystallization

$\mathrm{MeOH}$

$3.4 \quad 12$

25

197.0 a

13

ZIF-8

Nylon

$\mathrm{MeOH}-\mathrm{MeOH}$

$-\quad 16$

20

$\mathrm{H}_{2} / \mathrm{N}_{2}$

139

4.3aㅗ

10

fiber crystallization

Water

$-\quad 2.0$

$\mathrm{H}_{2} / \mathrm{CH}_{4}$

$\mathrm{H}_{2} / \mathrm{CO}_{2} \quad 5730$ a

$\begin{array}{ll}\mathrm{H}_{2} / \mathrm{N}_{2} & \\ \mathrm{H}_{2} / \mathrm{CO}_{2} & 30\end{array}$

$\mathrm{H}_{2} / \mathrm{CO}_{2} \quad 30$

$\mathrm{H}_{2} / \mathrm{N}_{2}$

$\mathrm{H}_{2} / \mathrm{CH}_{4}$

$\mathrm{H}_{2} / \mathrm{N}_{2} \quad 113$ a

$\mathrm{H}_{2} / \mathrm{CO}_{2} \quad 43.2^{\mathrm{a}}$

$\mathrm{H}_{2} / \mathrm{N}_{2}$

$\mathrm{H}_{2} / \mathrm{CH}_{4}$

$\mathrm{H}_{2} / \mathrm{N}_{2} \quad 20.8^{a}$

$\mathrm{H}_{2} / \mathrm{CH}_{4}$

$\mathrm{H}_{2} / \mathrm{CO}_{2} \quad 201.4^{\text {a }}$

$\mathrm{H}_{2} / \mathrm{N}_{2}$
$\mathrm{H}_{2} / \mathrm{CO}_{2} \quad 1.9 a$

$\mathrm{H}_{2} / \mathrm{N}_{2}$

$\mathrm{H}_{2} / \mathrm{CH}_{4}$

$\mathrm{H}_{2} / \mathrm{CO}_{2} \quad 14$

$\mathrm{H}_{2} / \mathrm{N}_{2}$

$\mathrm{H}_{2} / \mathrm{CH}_{4}$

$\mathrm{H}_{2} / \mathrm{CO}_{2} \quad 15.8$

$\begin{array}{ll}\mathrm{H}_{2} / \mathrm{N}_{2} & 16.9\end{array}$

$\mathrm{H}_{2} / \mathrm{CH}_{4} \quad 16.7$

$17.1^{\mathrm{a}}$

7.3

4.9
4.8

4.6 a

12.1

$10.3^{\mathrm{a}}$

$10.4^{\mathrm{a}}$

$16.3^{\mathrm{a}}$

18.1 a

$5^{\mathrm{a}}$

11 a

12 a

4.2

12.5

4.6

4.6
8.2

8.2
9.8 


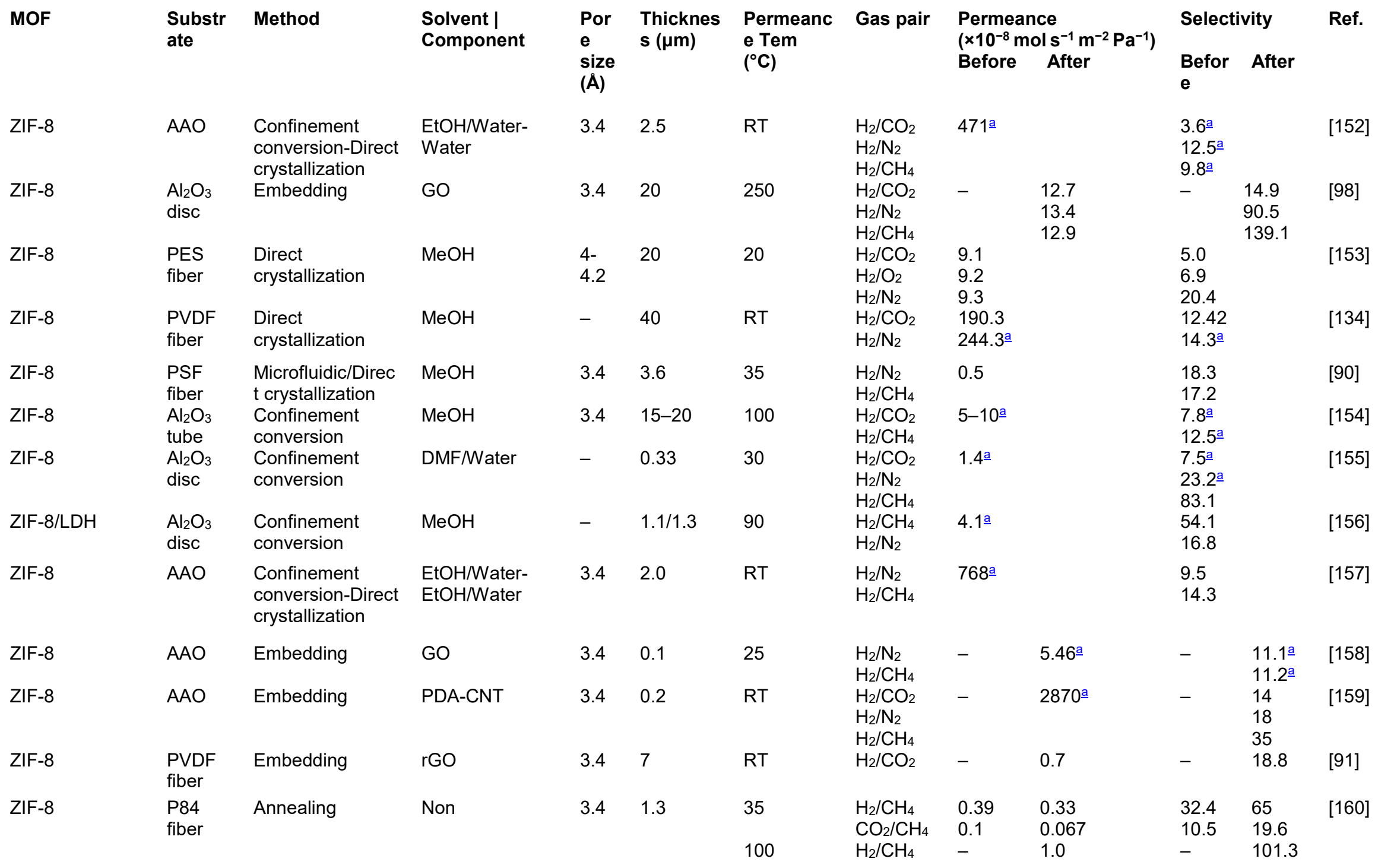


(A)

$\left({ }^{\circ} \mathrm{C}\right)$

Before After

ZIF-8

$\begin{array}{ll}\text { PVDF } & \text { Direct } \\ \text { fiber } & \text { crystallization }\end{array}$

Water

- 1$$
\mathrm{Al}_{2} \mathrm{O}_{3}
$$$$
\text { Spin }
$$$$
\text { Coating/Layer by }
$$

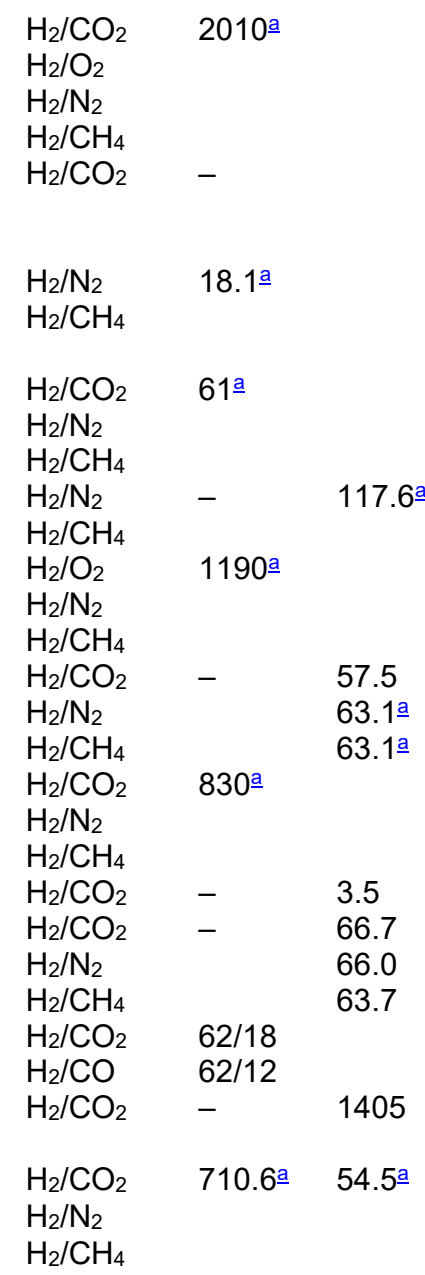




\begin{tabular}{|c|c|c|c|c|c|c|c|c|c|c|c|c|}
\hline MOF & $\begin{array}{l}\text { Substr } \\
\text { ate }\end{array}$ & Method & $\begin{array}{l}\text { Solvent | } \\
\text { Component }\end{array}$ & $\begin{array}{l}\text { Por } \\
\text { e } \\
\text { size } \\
(\AA)\end{array}$ & $\begin{array}{l}\text { Thicknes } \\
\mathrm{s}(\mu \mathrm{m})\end{array}$ & $\begin{array}{l}\text { Permeanc } \\
\text { e Tem } \\
\left({ }^{\circ} \mathrm{C}\right)\end{array}$ & Gas pair & $\begin{array}{l}\text { Permea } \\
\left(\times 10^{-8} \mathrm{~m}\right. \\
\text { Before }\end{array}$ & $\begin{array}{l}\left.\text { ol } \mathrm{s}^{-1} \mathrm{~m}^{-2} \mathrm{~Pa}^{-1}\right) \\
\text { After }\end{array}$ & $\begin{array}{l}\text { Befor } \\
\text { e }\end{array}$ & After & Ref. \\
\hline ZIF-9 & $\begin{array}{l}\text { P84 } \\
\text { fiber }\end{array}$ & $\begin{array}{l}\text { Heteroepitaxial } \\
\text { growth }\end{array}$ & ZIF-8 & 3 & $0.9 / 1.1$ & 150 & $\mathrm{H}_{2} / \mathrm{CO}_{2}$ & 7.2 & 8.4 & 8.0 & 9.6 & [168] \\
\hline ZIF-9 & $\begin{array}{l}\text { P84 } \\
\text { fiber }\end{array}$ & $\begin{array}{l}\text { Heteroepitaxial } \\
\text { growth }\end{array}$ & ZIF-67 & 3 & $1.0 / 1.1$ & 150 & $\mathrm{H}_{2} / \mathrm{CO}_{2}$ & 7.2 & 5.3 & 8.0 & 9.0 & [168] \\
\hline ZIF-22 & $\begin{array}{l}\mathrm{TiO}_{2} \\
\text { disks }\end{array}$ & Grafting & APTES & 3 & 40 & 50 & $\begin{array}{l}\mathrm{H}_{2} / \mathrm{CO}_{2} \\
\mathrm{H}_{2} / \mathrm{N}_{2} \\
\mathrm{H}_{2} / \mathrm{CH}_{4}\end{array}$ & 16 & & $\begin{array}{l}7.2 \\
6.4 \\
5.2\end{array}$ & & {$[106]$} \\
\hline ZIF-67 & $\begin{array}{l}\mathrm{Al}_{2} \mathrm{O}_{3} \\
\text { disc }\end{array}$ & $\begin{array}{l}\text { Heteroepitaxial } \\
\text { growth }\end{array}$ & ZIF-8 & - & 0.18 & RT & $\begin{array}{l}\mathrm{H}_{2} / \mathrm{CO}_{2} \\
\mathrm{H}_{2} / \mathrm{N}_{2} \\
\mathrm{H}_{2} / \mathrm{CH}_{4}\end{array}$ & $\begin{array}{l}2.1 \\
3.4 \\
2.2\end{array}$ & $\begin{array}{l}1.1 \\
2.1 \\
1.7\end{array}$ & $\begin{array}{l}6.5 \\
8.9 \\
5.5\end{array}$ & $\begin{array}{l}13.2 \\
9.3 \\
11.1\end{array}$ & {$[107]$} \\
\hline ZIF-78 & $\begin{array}{l}\text { Porous } \\
\mathrm{ZnO}\end{array}$ & Grafting & DMF & 3.8 & 25 & RT & $\begin{array}{l}\mathrm{H}_{2} / \mathrm{CO}_{2} \\
\mathrm{H}_{2} / \mathrm{N}_{2} \\
\mathrm{H}_{2} / \mathrm{CH}_{4}\end{array}$ & 10 & & $\begin{array}{l}9.5 \\
5.7 \\
6.4\end{array}$ & & [108] \\
\hline ZIF-90 & $\begin{array}{l}\alpha-\mathrm{Al}_{2} \mathrm{O}_{3} \\
\text { disks }\end{array}$ & Grafting & Ethanolamine & 3.5 & 20 & 200 & $\begin{array}{l}\mathrm{H}_{2} / \mathrm{CO}_{2} \\
\mathrm{H}_{2} / \mathrm{N}_{2} \\
\mathrm{H}_{2} / \mathrm{CH}_{4}\end{array}$ & $\begin{array}{l}23.7 \\
24.8 \\
25.1\end{array}$ & $\begin{array}{l}20.2 \\
21.4 \\
19.4\end{array}$ & $\begin{array}{l}7.3 \\
11.7 \\
15.3\end{array}$ & $\begin{array}{l}15.3 \\
15.8 \\
18.9\end{array}$ & {$[101,102]$} \\
\hline \multirow[t]{2}{*}{ ZIF-90 } & \multirow{2}{*}{$\begin{array}{l}\mathrm{Al}_{2} \mathrm{O}_{3} \\
\text { disc }\end{array}$} & \multirow[t]{2}{*}{ Grafting } & \multirow[t]{2}{*}{ APTES } & \multirow[t]{2}{*}{3.5} & \multirow[t]{2}{*}{20} & \multirow[t]{2}{*}{225} & $\mathrm{H}_{2} / \mathrm{CO}_{2}$ & 29.1 & 28.2 & 7.2 & 20.1 & {$[103,105]$} \\
\hline & & & & & & & $\mathrm{H}_{2} / \mathrm{CH}_{4}$ & 29.0 & 28.5 & 15.4 & 70.5 & \\
\hline ZIF-90 & $\begin{array}{l}\text { Torlon } \\
\text { fiber }\end{array}$ & $\begin{array}{l}\text { Direct } \\
\text { crystallization }\end{array}$ & $\mathrm{MeOH}$ & 3.5 & 5 & 35 & $\begin{array}{l}\mathrm{H}_{2} / \mathrm{CO}_{2} \\
\mathrm{H}_{2} / \mathrm{N}_{2}\end{array}$ & \multicolumn{2}{|l|}{$19.4^{\mathrm{a}}$} & $\begin{array}{l}1.8^{a} \\
6.3^{a}\end{array}$ & & [104] \\
\hline ZIF-94 & $\begin{array}{l}\text { P84 } \\
\text { fiber }\end{array}$ & Grafting & Nonylamine & - & 7.1 & 35 & $\mathrm{H}_{2} / \mathrm{CH}_{4}$ & 0.42 & 1.6 & 136 & 85.6 & [109] \\
\hline ZIF-95 & $\begin{array}{l}\mathrm{a}-\mathrm{Al}_{2} \mathrm{O}_{3} \\
\text { disks }\end{array}$ & Grafting & APTES & 3.7 & 30 & RT & $\mathrm{H}_{2} / \mathrm{CO}_{2}$ & 195 & & 25.7 & & [110] \\
\hline $\mathrm{Zn}_{2}(\mathrm{bim})_{4}$ & $\alpha-\mathrm{Al}_{2} \mathrm{O}_{3}$ & Hot drop coating & DMF/DEA & 2.1 & 0.001 & 25 & $\mathrm{H}_{2} / \mathrm{CO}_{2}$ & $76.4 \pm 1$ & & $230 \pm 3$ & & [111] \\
\hline $\mathrm{Zn}_{2}(\mathrm{bim})_{4}$ & $\alpha-\mathrm{Al}_{2} \mathrm{O}_{3}$ & Hot drop coating & DMF/DEA & 2.1 & 0.01 & 25 & $\mathrm{H}_{2} / \mathrm{CO}_{2}$ & 80 & & 166 & & [112] \\
\hline \multirow[t]{2}{*}{$\mathrm{Co}_{2}(\mathrm{bim})_{4}$} & \multirow[t]{2}{*}{$\alpha-\mathrm{Al}_{2} \mathrm{O}_{3}$} & \multirow[t]{2}{*}{$\begin{array}{l}\text { Vapor phase } \\
\text { transformation }\end{array}$} & \multirow[t]{2}{*}{ EGME } & \multirow[t]{2}{*}{-} & \multirow[t]{2}{*}{0.057} & \multirow[t]{2}{*}{30} & $\begin{array}{l}\mathrm{H}_{2} / \mathrm{CO}_{2} \\
\mathrm{H}_{2} / \mathrm{N}_{2}\end{array}$ & 12.7 & & $\begin{array}{l}42.7 \\
38.4\end{array}$ & & [113] \\
\hline & & & & & & & $\mathrm{H}_{2} / \mathrm{CH}_{4}$ & & & 51.3 & & \\
\hline [COF-300]-MOF & $\begin{array}{l}\mathrm{SiO}_{2} \\
\text { disc }\end{array}$ & $\begin{array}{l}\text { Heteroepitaxial } \\
\text { growth }\end{array}$ & $\mathrm{Zn}_{2}(\mathrm{bdc})_{2}(\mathrm{dabco}$ & - & $55 / 42$ & RT & $\mathrm{H}_{2} / \mathrm{CO}_{2}$ & 81 & 46 & 6.0 & 12.6 & [119] \\
\hline $\begin{array}{l}\text { [COF-300]-[ZIF- } \\
\text { 8] }\end{array}$ & $\begin{array}{l}\mathrm{SiO}_{2} \\
\text { disc }\end{array}$ & $\begin{array}{l}\text { Heteroepitaxial } \\
\text { growth }\end{array}$ & ZIF-8 & - & $58 / 42$ & RT & $\mathrm{H}_{2} / \mathrm{CO}_{2}$ & 81 & 36 & 6.0 & 13.5 & [119] \\
\hline
\end{tabular}




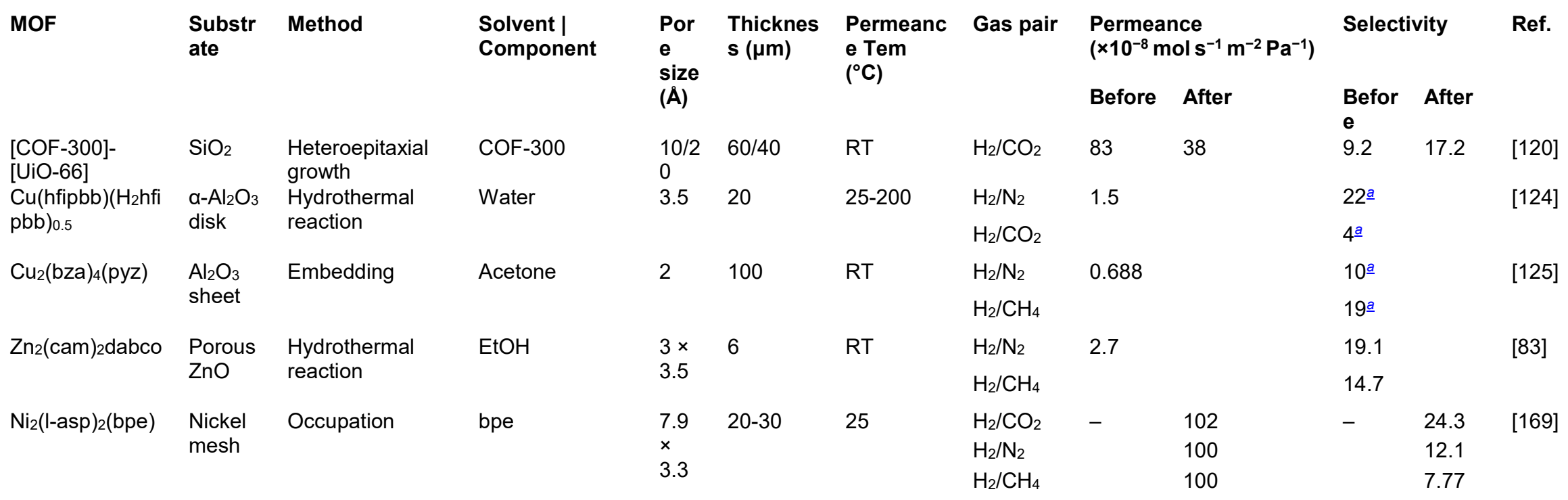




\section{Acknowledgements}

The authors gratefully acknowledge funding under grant KTP 11326 from Innovate UK, the Knowledge Transfer Partnerships and NanoSUN Ltd.

\section{References}

[1] Miranda LCM, Lima CAS. On the forecasting of the challenging world future scenarios. Technological Forecasting and Social Change. 2011;78:1445-70.

[2] Abas N, Kalair A, Khan N. Review of fossil fuels and future energy technologies. Futures. 2015;69:31-49.

[3] BP. BP Statistical Review of World Energy 67th edition. 2018. p. 1-56.

[4] Ellabban O, Abu-Rub H, Blaabjerg F. Renewable energy resources: Current status, future prospects and their enabling technology. Renewable and Sustainable Energy Reviews. 2014;39:748-64.

[5] Liang X. Emerging Power Quality Challenges Due to Integration of Renewable Energy Sources. IEEE Transactions on Industry Applications. 2017;53:855-66.

[6] Abe JO, Popoola API, Ajenifuja E, Popoola OM. Hydrogen energy, economy and storage: Review and recommendation. International Journal of Hydrogen Energy. 2019;44:15072-86.

[7] Lin R-H, Zhao Y-Y, Wu B-D. Toward a hydrogen society: Hydrogen and smart grid integration. International Journal of Hydrogen Energy. 2020;45:20164-75.

[8] Smoliński A, Howaniec N. Hydrogen energy, electrolyzers and fuel cells - The future of modern energy sector. International Journal of Hydrogen Energy. 2020;45:5607.

[9] Cipriani G, Di Dio V, Genduso F, La Cascia D, Liga R, Miceli R, et al. Perspective on hydrogen energy carrier and its automotive applications. International Journal of Hydrogen Energy. 2014;39:8482-94.

[10] Marchenko OV, Solomin SV. The future energy: Hydrogen versus electricity. International Journal of Hydrogen Energy. 2015;40:3801-5.

[11] Acar C, Dincer I, Naterer GF. Clean hydrogen and power from impure water. Journal of Power Sources. 2016;331:189-97.

[12] Pinsky R, Sabharwall P, Hartvigsen J, O'Brien J. Comparative review of hydrogen production technologies for nuclear hybrid energy systems. Progress in Nuclear Energy. 2020;123:103317.

[13] Korotkikh O, Farrauto R. Selective catalytic oxidation of $\mathrm{CO}$ in $\mathrm{H}_{2}$ : fuel cell applications. Catalysis Today. 2000;62:249-54.

[14] Song C. Fuel processing for low-temperature and high-temperature fuel cells: Challenges, and opportunities for sustainable development in the 21 st century. Catalysis Today. 2002;77:17-49.

[15] Borup R, Meyers J, Pivovar B, Kim YS, Mukundan R, Garland N, et al. Scientific Aspects of Polymer Electrolyte Fuel Cell Durability and Degradation. Chemical Reviews. 2007; 107:3904-51.

[16] More A. Global Hydrogen and Fuel Cells Market 2019 Analysis by Industry-Size, Share, Trends Evaluation, Revenue, Growing-Demand, Regional Analysis \& Forecast 2025. 2019.

[17] Mousavi J, Parvini M. Analyzing effective factors on leakage-induced hydrogen fires. Journal of Loss Prevention in the Process Industries. 2016;40:29-42.

[18] Hadef H, Negrou B, Ayuso TG, Djebabra M, Ramadan M. Preliminary hazard identification for risk assessment on a complex system for hydrogen production. International Journal of Hydrogen Energy. 2020;45:11855-65.

[19] Mair GW, Thomas S, Schalau B, Wang B. Safety criteria for the transport of hydrogen in permanently mounted composite pressure vessels. International Journal of Hydrogen Energy. 2020 . 
[20] Uyar TS, Beşikci D. Integration of hydrogen energy systems into renewable energy systems for better design of $100 \%$ renewable energy communities. International Journal of Hydrogen Energy. 2017;42:2453-6.

[21] Hanley ES, Deane JP, Gallachóir BPÓ. The role of hydrogen in low carbon energy futures-A review of existing perspectives. Renewable and Sustainable Energy Reviews. 2018;82:3027-45.

[22] Martin A, Agnoletti M-F, Brangier E. Users in the design of Hydrogen Energy Systems: A systematic review. International Journal of Hydrogen Energy. 2020;45:11889-900.

[23] Yan W-M, Chu H-S, Lu M-X, Weng F-B, Jung G-B, Lee C-Y. Degradation of proton exchange membrane fuel cells due to $\mathrm{CO}$ and $\mathrm{CO}_{2}$ poisoning. Journal of Power Sources. 2009; $188: 141-7$.

[24] Cheng X, Shi Z, Glass N, Zhang L, Zhang J, Song D, et al. A review of PEM hydrogen fuel cell contamination: Impacts, mechanisms, and mitigation. Journal of Power Sources. 2007; 165:739-56.

[25] Besancon BM, Hasanov V, Imbault-Lastapis R, Benesch R, Barrio M, Mølnvik MJ. Hydrogen quality from decarbonized fossil fuels to fuel cells. International Journal of Hydrogen Energy. 2009;34:2350-60.

[26] Standardisation IOf. Hydrogen fuel - Product specification Part 2: Proton exchange membrane (PEM) fuel cell applications for road vehicles. Switzerland, 2012.

[27] Nikolaidis P, Poullikkas A. A comparative overview of hydrogen production processes. Renewable and Sustainable Energy Reviews. 2017;67:597-611.

[28] Holladay JD, Hu J, King DL, Wang Y. An overview of hydrogen production technologies. Catalysis Today. 2009;139:244-60.

[29] Sircar S, Golden TC. Purification of Hydrogen by Pressure Swing Adsorption. Separation Science and Technology. 2000;35:667-87.

[30] Veziroglu TN, Zaginaichenko SY, Schur DV, Baranowski B, Shpak AP, Skorokhod VV. Hydrogen Materials Science and Chemistry of Carbon Nanomaterials: Proceedings of the NATO Advanced Research Workshop on Hydrogen Materials Science an Chemistry of Carbon Nanomaterials, Sudak, Crimea, Ukraine, September 14-20, 2003: Springer Science \& Business Media; 2006.

[31] Muradov N. Low to near-zero $\mathrm{CO}_{2}$ production of hydrogen from fossil fuels: Status and perspectives. International Journal of Hydrogen Energy. 2017;42:14058-88.

[32] Abdalla AM, Hossain S, Nisfindy OB, Azad AT, Dawood M, Azad AK. Hydrogen production, storage, transportation and key challenges with applications: A review. Energy Conversion and Management. 2018;165:602-27.

[33] Ehteshami SMM, Chan SH. The role of hydrogen and fuel cells to store renewable energy in the future energy network - potentials and challenges. Energy Policy. 2014;73:103-9.

[34] Gandia LM, Arzamendi G, Dieguez PM. Renewable hydrogen technologies : production, purification, storage, applications and safety: Elsevier Science; 2013.

[35] Voldsund M, Jordal K, Anantharaman R. Hydrogen production with $\mathrm{CO}_{2}$ capture. International Journal of Hydrogen Energy. 2016;41:4969-92.

[36] Grashoff BGJ, Pilkington CE, Corti CW. The Purification of Hydrogen. 1983:157-69.

[37] Abdeljaoued A, Relvas F, Mendes A, Chahbani MH. Simulation and experimental results of a PSA process for production of hydrogen used in fuel cells. Journal of Environmental Chemical Engineering. 2018;6:338-55.

[38] Barelli L, Bidini G, Gallorini F, Servili S. Hydrogen production through sorptionenhanced steam methane reforming and membrane technology: A review. Energy. 2008;33:554-70. 
[39] Cheng YS, Peña MA, Fierro JL, Hui DCW, Yeung KL. Performance of alumina, zeolite, palladium, $\mathrm{Pd}-\mathrm{Ag}$ alloy membranes for hydrogen separation from Towngas mixture. Journal of Membrane Science. 2002;204:329-40.

[40] Perez EV, Balkus KJ, Ferraris JP, Musselman IH. Mixed-matrix membranes containing MOF-5 for gas separations. Journal of Membrane Science. 2009;328:165-73.

[41] Yin H, Yip ACK. A review on the production and purification of biomass-derived hydrogen using emerging membrane technologies. Catalysts. 2017;7.

[42] Zhang Y, Feng X, Yuan S, Zhou J, Wang B. Challenges and recent advances in MOFpolymer composite membranes for gas separation. Inorganic Chemistry Frontiers. 2016;3:896909.

[43] Li J-R, Kuppler RJ, Zhou H-C. Selective gas adsorption and separation in metal-organic frameworks. Chemical Society Reviews. 2009;38:1477-504.

[44] Adams R, Carson C, Ward J, Tannenbaum R, Koros W. Metal organic framework mixed matrix membranes for gas separations. Microporous and Mesoporous Materials. 2010;131:1320.

[45] Dong G, Li H, Chen V. Challenges and opportunities for mixed-matrix membranes for gas separation. Journal of Materials Chemistry A. 2013;1:4610-30.

[46] Qiu S, Xue M, Zhu G. Metal-organic framework membranes: from synthesis to separation application. Chemical Society Reviews. 2014;43:6116-40.

[47] Li W. Metal-organic framework membranes: Production, modification, and applications. Progress in Materials Science. 2019;100:21-63.

[48] Azar ANV, Velioglu S, Keskin S. Large-Scale Computational Screening of Metal Organic Framework (MOF) Membranes and MOF-Based Polymer Membranes for $\mathrm{H}_{2} / \mathrm{N}_{2}$ Separations. ACS Sustain Chem Eng. 2019;7:9525-36.

[49] Lu GQ, Diniz da Costa JC, Duke M, Giessler S, Socolow R, Williams RH, et al. Inorganic membranes for hydrogen production and purification: A critical review and perspective. $\mathrm{J}$ Colloid Interface Sci. 2007;314:589-603.

[50] Drioli E, Barbieri G, Royal Society of C. Membrane engineering for the treatment of gases. Volume 1, Gas-separation problems with membranes Royal Society of Chemistry; 2011.

[51] Li P, Wang Z, Qiao Z, Liu Y, Cao X, Li W, et al. Recent developments in membranes for efficient hydrogen purification. Journal of Membrane Science. 2015;495:130-68.

[52] Koros WJ, Fleming GK. Membrane-based gas separation. Journal of Membrane Science. 1993;83:1-80.

[53] Nenoff TM, Spontak RJ, Aberg CM. Membranes for Hydrogen Purification: An Important Step toward a Hydrogen-Based Economy. MRS Bulletin. 2006;31:735-44.

[54] Tao Z, Yan L, Qiao J, Wang B, Zhang L, Zhang J. A review of advanced protonconducting materials for hydrogen separation. Progress in Materials Science. 2015;74:1-50.

[55] Ritter JA, Ebner AD. State - of - the - Art Adsorption and Membrane Separation Processes for Hydrogen Production in the Chemical and Petrochemical Industries. Separation Science and Technology. 2007;42:1123-93.

[56] Freeman BD. Basis of Permeability/Selectivity Tradeoff Relations in Polymeric Gas Separation Membranes. Macromolecules. 1999;32:375-80.

[57] Sanders DF, Smith ZP, Guo R, Robeson LM, McGrath JE, Paul DR, et al. Energy-efficient polymeric gas separation membranes for a sustainable future: A review. Polymer. 2013;54:4729-61.

[58] Bernardo P, Drioli E, Golemme G. Membrane Gas Separation: A Review/State of the Art. Industrial \& Engineering Chemistry Research. 2009;48:4638-63.

[59] Strathmann HJAj. Membrane separation processes: current relevance and future opportunities. 2001;47:1077-87. 
[60] Ockwig NW, Nenoff TM. Membranes for Hydrogen Separation. Chemical Reviews. 2007;107:4078-110.

[61] Janiak C, Vieth JK. MOFs, MILs and more: concepts, properties and applications for porous coordination networks (PCNs). New Journal of Chemistry. 2010;34:2366-88.

[62] Liu Y, Ng Z, Khan EA, Jeong H-K, Ching C-b, Lai Z. Synthesis of continuous MOF-5 membranes on porous $\alpha$-alumina substrates. Microporous and Mesoporous Materials. 2009;118:296-301.

[63] Yoo Y, Lai Z, Jeong H-K. Fabrication of MOF-5 membranes using microwave-induced rapid seeding and solvothermal secondary growth. Microporous and Mesoporous Materials. 2009; 123:100-6.

[64] Zhao Z, Ma X, Li Z, Lin YS. Synthesis, characterization and gas transport properties of MOF-5 membranes. Journal of Membrane Science. 2011;382:82-90.

[65] Kloutse FA, Hourri A, Natarajan S, Benard P, Chahine R. Hydrogen separation by adsorption: Experiments and modelling of $\mathrm{H}_{2}-\mathrm{N}_{2}-\mathrm{CO}_{2}$ and $\mathrm{H}_{2}-\mathrm{CH}_{4}-\mathrm{CO}_{2}$ mixtures adsorption on CuBTC and MOF-5. Microporous and Mesoporous Materials. 2018;271:175-85.

[66] Loiseau T, Serre C, Huguenard C, Fink G, Taulelle F, Henry M, et al. A Rationale for the Large Breathing of the Porous Aluminum Terephthalate (MIL-53) Upon Hydration. 2004;10:1373-82.

[67] Li W, Su P, Zhang G, Shen C, Meng Q. Preparation of continuous $\mathrm{NH}_{2}-\mathrm{MIL}-53$ membrane on ammoniated polyvinylidene fluoride hollow fiber for efficient $\mathrm{H}_{2}$ purification. Journal of Membrane Science. 2015;495:384-91.

[68] Li W, Zhang Y, Zhang C, Meng Q, Xu Z, Su P, et al. Transformation of metal-organic frameworks for molecular sieving membranes. Nature Communications. 2016;7:11315.

[69] Li W, Yang Z, Zhang G, Fan Z, Meng Q, Shen C, et al. Stiff metal-organic frameworkpolyacrylonitrile hollow fiber composite membranes with high gas permeability. Journal of Materials Chemistry A. 2014;2:2110-8.

[70] Zhou S, Zou X, Sun F, Zhang F, Fan S, Zhao H, et al. Challenging fabrication of hollow ceramic fiber supported $\mathrm{Cu}_{3}(\mathrm{BTC})_{2}$ membrane for hydrogen separation. Journal of Materials Chemistry. 2012;22:10322-8.

[71] Shah MN, Gonzalez MA, McCarthy MC, Jeong H-K. An Unconventional Rapid Synthesis of High Performance Metal-Organic Framework Membranes. Langmuir. 2013;29:7896-902.

[72] Ben T, Lu C, Pei C, Xu S, Qiu S. Polymer-Supported and Free-Standing Metal-Organic Framework Membrane. 2012;18:10250-3.

[73] Díaz-García M, Mayoral Á, Díaz I, Sánchez-Sánchez M. Nanoscaled M-MOF-74 Materials Prepared at Room Temperature. Crystal Growth \& Design. 2014;14:2479-87.

[74] Wang N, Mundstock A, Liu Y, Huang A, Caro J. Amine-modified Mg-MOF-74/CPO-27$\mathrm{Mg}$ membrane with enhanced $\mathrm{H}_{2} / \mathrm{CO}_{2}$ separation. Chemical Engineering Science. 2015;124:27-36.

[75] Herm ZR, Swisher JA, Smit B, Krishna R, Long JR. Metal-Organic Frameworks as Adsorbents for Hydrogen Purification and Precombustion Carbon Dioxide Capture. Journal of the American Chemical Society. 2011;133:5664-7.

[76] Herm ZR, Krishna R, Long JR. Reprint of: $\mathrm{CO}_{2} / \mathrm{CH}_{4}, \mathrm{CH}_{4} / \mathrm{H}_{2}$ and $\mathrm{CO}_{2} / \mathrm{CH}_{4} / \mathrm{H}_{2}$ separations at high pressures using $\mathrm{Mg}_{2}$ (dobdc). Microporous and Mesoporous Materials. 2012;157:94100.

[77] Krishna R, van Baten JM. Investigating the potential of MgMOF-74 membranes for $\mathrm{CO}_{2}$ capture. Journal of Membrane Science. 2011;377:249-60.

[78] Liu J, Benin AI, Furtado AMB, Jakubczak P, Willis RR, LeVan MD. Stability Effects on $\mathrm{CO}_{2}$ Adsorption for the DOBDC Series of Metal-Organic Frameworks. Langmuir. 2011;27:11451-6. 
[79] Lee D-J, Li Q, Kim H, Lee K. Preparation of Ni-MOF-74 membrane for $\mathrm{CO}_{2}$ separation by layer-by-layer seeding technique. Microporous and Mesoporous Materials. 2012;163:16977.

[80] Al-Naddaf Q, Thakkar H, Rezaei F. Novel Zeolite-5A@MOF-74 Composite Adsorbents with Core-Shell Structure for H2 Purification. ACS Applied Materials \& Interfaces. 2018;10:29656-66.

[81] Banu A-M, Friedrich D, Brandani S, Düren T. A Multiscale Study of MOFs as Adsorbents in $\mathrm{H}_{2}$ PSA Purification. Industrial \& Engineering Chemistry Research. 2013;52:9946-57.

[82] Friebe S, Geppert B, Steinbach F, Caro J. Metal-Organic Framework UiO-66 Layer: A Highly Oriented Membrane with Good Selectivity and Hydrogen Permeance. ACS Applied Materials \& Interfaces. 2017;9:12878-85.

[83] Huang K, Liu S, Li Q, Jin W. Preparation of novel metal-carboxylate system MOF membrane for gas separation. Separation and Purification Technology. 2013;119:94-101.

[84] Huang A, Chen Y, Liu Q, Wang N, Jiang J, Caro J. Synthesis of highly hydrophobic and permselective metal-organic framework $\mathrm{Zn}(\mathrm{BDC})(\mathrm{TED})_{0.5}$ membranes for $\mathrm{H}_{2} / \mathrm{CO}_{2}$ separation. Journal of Membrane Science. 2014;454:126-32.

[85] Zhou S, Zou X, Sun F, Ren H, Liu J, Zhang F, et al. Development of hydrogen-selective CAU-1 MOF membranes for hydrogen purification by 'dual-metal-source' approach. International Journal of Hydrogen Energy. 2013;38:5338-47.

[86] Jin H, Wollbrink A, Yao R, Li Y, Caro J, Yang W. A novel CAU-10-H MOF membrane for hydrogen separation under hydrothermal conditions. Journal of Membrane Science. 2016;513:40-6.

[87] Park KS, Ni Z, Côté AP, Choi JY, Huang R, Uribe-Romo FJ, et al. Exceptional chemical and thermal stability of zeolitic imidazolate frameworks. 2006;103:10186-91.

[88] Novaković SB, Bogdanović GA, Heering C, Makhloufi G, Francuski D, Janiak C. ChargeDensity Distribution and Electrostatic Flexibility of ZIF-8 Based on High-Resolution X-ray Diffraction Data and Periodic Calculations. Inorganic Chemistry. 2015;54:2660-70.

[89] Li W, Meng Q, Li X, Zhang C, Fan Z, Zhang G. Non-activation ZnO array as a buffering layer to fabricate strongly adhesive metal-organic framework/PVDF hollow fiber membranes. Chemical Communications. 2014;50:9711-3.

[90] Cacho-Bailo F, Catalán-Aguirre S, Etxeberría-Benavides M, Karvan O, Sebastian V, Téllez C, et al. Metal-organic framework membranes on the inner-side of a polymeric hollow fiber by microfluidic synthesis. Journal of Membrane Science. 2015;476:277-85.

[91] Li W, Zhang Y, Su P, Xu Z, Zhang G, Shen C, et al. Metal-organic framework channelled graphene composite membranes for $\mathrm{H}_{2} / \mathrm{CO}_{2}$ separation. Journal of Materials Chemistry A. 2016;4:18747-52.

[92] Bux H, Liang F, Li Y, Cravillon J, Wiebcke M, Caro J. Zeolitic Imidazolate Framework Membrane with Molecular Sieving Properties by Microwave-Assisted Solvothermal Synthesis. Journal of the American Chemical Society. 2009;131:16000-1.

[93] Xie Z, Yang J, Wang J, Bai J, Yin H, Yuan B, et al. Deposition of chemically modified $\alpha-$ $\mathrm{Al}_{2} \mathrm{O}_{3}$ particles for high performance ZIF-8 membrane on a macroporous tube. Chemical Communications. 2012;48:5977-9.

[94] Zhang S, Wang Z, Ren H, Zhang F, Jin J. Nanoporous film-mediated growth of ultrathin and continuous metal-organic framework membranes for high-performance hydrogen separation. Journal of Materials Chemistry A. 2017;5:1962-6.

[95] Hou J, Wei Y, Zhou S, Wang Y, Wang H. Highly efficient $\mathrm{H}_{2} / \mathrm{CO}_{2}$ separation via an ultrathin metal-organic framework membrane. Chemical Engineering Science. 2018;182:1808 . 
[96] Li W, Shi J, Li Z, Wu W, Xia Y, Yu Y, et al. Hydrothermally Reduced Graphene Oxide Interfaces for Synthesizing High-Performance Metal-Organic Framework Hollow Fiber Membranes. Advanced Materials Interfaces. 2018;5:1800032.

[97] Kim S, Choi J, Choi C, Heo J, Kim DW, Lee JY, et al. Pore-Size-Tuned Graphene Oxide Frameworks as Ion-Selective and Protective Layers on Hydrocarbon Membranes for Vanadium Redox-Flow Batteries. Nano Letters. 2018;18:3962-8.

[98] Huang A, Liu Q, Wang N, Zhu Y, Caro J. Bicontinuous Zeolitic Imidazolate Framework ZIF-8@GO Membrane with Enhanced Hydrogen Selectivity. Journal of the American Chemical Society. 2014;136:14686-9.

[99] Zhang C, Xiao Y, Liu D, Yang Q, Zhong C. A hybrid zeolitic imidazolate framework membrane by mixed-linker synthesis for efficient $\mathrm{CO}_{2}$ capture. Chemical Communications. 2013;49:600-2.

[100] Huang Y, Xiao Y, Huang H, Liu Z, Liu D, Yang Q, et al. Ionic liquid functionalized multi-walled carbon nanotubes/zeolitic imidazolate framework hybrid membranes for efficient $\mathrm{H}_{2} / \mathrm{CO}_{2}$ separation. Chemical Communications. 2015;51:17281-4.

[101] Huang A, Dou W, Caro J. Steam-Stable Zeolitic Imidazolate Framework ZIF-90 Membrane with Hydrogen Selectivity through Covalent Functionalization. Journal of the American Chemical Society. 2010;132:15562-4.

[102] Huang A, Caro J. Covalent Post-Functionalization of Zeolitic Imidazolate Framework ZIF-90 Membrane for Enhanced Hydrogen Selectivity. 2011;50:4979-82.

[103] Huang A, Wang N, Kong C, Caro J. Organosilica-Functionalized Zeolitic Imidazolate Framework ZIF-90 Membrane with High Gas-Separation Performance. 2012;51:10551-5.

[104] Brown AJ, Johnson JR, Lydon ME, Koros WJ, Jones CW, Nair S. Continuous Polycrystalline Zeolitic Imidazolate Framework-90 Membranes on Polymeric Hollow Fibers. 2012;51:10615-8.

[105] Huang A, Liu Q, Wang N, Caro J. Organosilica functionalized zeolitic imidazolate framework ZIF-90 membrane for $\mathrm{CO}_{2} / \mathrm{CH}_{4}$ separation. Microporous and Mesoporous Materials. 2014;192:18-22.

[106] Huang A, Bux H, Steinbach F, Caro J. Molecular-Sieve Membrane with Hydrogen Permselectivity: ZIF-22 in LTA Topology Prepared with 3-Aminopropyltriethoxysilane as Covalent Linker. 2010;49:4958-61.

[107] Knebel A, Wulfert-Holzmann P, Friebe S, Pavel J, Strauß I, Mundstock A, et al. Hierarchical Nanostructures of Metal-Organic Frameworks Applied in Gas Separating ZIF-8on-ZIF-67 Membranes. 2018;24:5728-33.

[108] Dong X, Huang K, Liu S, Ren R, Jin W, Lin YS. Synthesis of zeolitic imidazolate framework-78 molecular-sieve membrane: defect formation and elimination. Journal of Materials Chemistry. 2012;22:19222-7.

[109] Cacho-Bailo F, Etxeberría-Benavides M, Karvan O, Téllez C, Coronas J. Sequential amine functionalization inducing structural transition in an aldehyde-containing zeolitic imidazolate framework: application to gas separation membranes. CrystEngComm. 2017;19:1545-54.

[110] Huang A, Chen Y, Wang N, Hu Z, Jiang J, Caro J. A highly permeable and selective zeolitic imidazolate framework ZIF-95 membrane for $\mathrm{H}_{2} / \mathrm{CO}_{2}$ separation. Chemical Communications. 2012;48:10981-3.

[111] Peng Y, Li Y, Ban Y, Jin H, Jiao W, Liu X, et al. Metal-organic framework nanosheets as building blocks for molecular sieving membranes. 2014;346:1356-9.

[112] Peng Y, Li Y, Ban Y, Yang W. Two-Dimensional Metal-Organic Framework Nanosheets for Membrane-Based Gas Separation. 2017;56:9757-61.

[113] Nian P, Liu H, Zhang X. Bottom-up fabrication of two-dimensional Co-based zeolitic imidazolate framework tubular membranes consisting of nanosheets by vapor phase 
transformation of Co-based gel for $\mathrm{H}_{2} / \mathrm{CO}_{2}$ separation. Journal of Membrane Science. 2019;573:200-9.

[114] Xiang, Wu, ZhangZhang, Fu, Hu, ZhangZhang. A 3D Canted Antiferromagnetic Porous Metal-Organic Framework with Anatase Topology through Assembly of an Analogue of Polyoxometalate. Journal of the American Chemical Society. 2005;127:16352-3.

[115] Xiang S, He Y, Zhang Z, Wu H, Zhou W, Krishna R, et al. Microporous metal-organic framework with potential for carbon dioxide capture at ambient conditions. Nature Communications. 2012;3:954.

[116] Agueda VI, Delgado JA, Uguina MA, Brea P, Spjelkavik AI, Blom R, et al. Adsorption and diffusion of $\mathrm{H}_{2}, \mathrm{~N}_{2}, \mathrm{CO}, \mathrm{CH}_{4}$ and $\mathrm{CO}_{2}$ in UTSA-16 metal-organic framework extrudates. Chemical Engineering Science. 2015;124:159-69.

[117] Delgado JA, Águeda VI, Uguina MA, Brea P, Grande CA. Comparison and evaluation of agglomerated MOFs in biohydrogen purification by means of pressure swing adsorption (PSA). Chemical Engineering Journal. 2017;326:117-29.

[118] Brea P, Delgado JA, Águeda VI, Uguina MA. Comparison between MOF UTSA-16 and BPL activated carbon in hydrogen purification by PSA. Chemical Engineering Journal. 2019;355:279-89.

[119] Fu J, Das S, Xing G, Ben T, Valtchev V, Qiu S. Fabrication of COF-MOF Composite Membranes and Their Highly Selective Separation of $\mathrm{H}_{2} / \mathrm{CO}_{2}$. Journal of the American Chemical Society. 2016;138:7673-80.

[120] Das S, Ben T. A [COF-300]-[UiO-66] composite membrane with remarkably high permeability and H2/CO2 separation selectivity. Dalton Transactions. 2018;47:7206-12.

[121] Fischer M, Hoffmann F, Fröba M. Metal-organic frameworks and related materials for hydrogen purification: Interplay of pore size and pore wall polarity. RSC Advances. 2012;2:4382-96.

[122] Wu H, Yao K, Zhu Y, Li B, Shi Z, Krishna R, et al. Cu-TDPAT, an rht-Type DualFunctional Metal-Organic Framework Offering Significant Potential for Use in $\mathrm{H}_{2}$ and Natural Gas Purification Processes Operating at High Pressures. The Journal of Physical Chemistry C. 2012;116:16609-18.

[123] Yin H, Shang J, Choi J, Yip ACK. Generation and extraction of hydrogen from lowtemperature water-gas-shift reaction by a ZIF-8-based membrane reactor. Microporous and Mesoporous Materials. 2019;280:347-56.

[124] Ranjan R, Tsapatsis M. Microporous Metal Organic Framework Membrane on Porous Support Using the Seeded Growth Method. Chemistry of Materials. 2009;21:4920-4.

[125] Takamizawa S, Takasaki Y, Miyake R. Single-Crystal Membrane for Anisotropic and Efficient Gas Permeation. Journal of the American Chemical Society. 2010;132:2862-3.

[126] Nandi S, De Luna P, Daff TD, Rother J, Liu M, Buchanan W, et al. A single-ligand ultramicroporous $\mathrm{MOF}$ for precombustion $\mathrm{CO}_{2}$ capture and hydrogen purification. 2015;1:e1500421.

[127] Hu Y, Dong X, Nan J, Jin W, Ren X, Xu N, et al. Metal-organic framework membranes fabricated via reactive seeding. Chemical Communications. 2011;47:737-9.

[128] Zhang F, Zou X, Gao X, Fan S, Sun F, Ren H, et al. Hydrogen Selective $\mathrm{NH}_{2}-\mathrm{MIL}-$ 53(Al) MOF Membranes with High Permeability. 2012;22:3583-90.

[129] Guo H, Zhu G, Hewitt IJ, Qiu S. "Twin Copper Source" Growth of Metal-Organic Framework Membrane: $\mathrm{Cu}_{3}(\mathrm{BTC})_{2}$ with High Permeability and Selectivity for Recycling H2. Journal of the American Chemical Society. 2009;131:1646-7.

[130] Nan J, Dong X, Wang W, Jin W, Xu N. Step-by-Step Seeding Procedure for Preparing HKUST-1 Membrane on Porous $\alpha$-Alumina Support. Langmuir. 2011;27:4309-12. 
[131] Mao Y, shi L, Huang H, Cao W, Li J, Sun L, et al. Room temperature synthesis of freestanding HKUST-1 membranes from copper hydroxide nanostrands for gas separation. Chemical Communications. 2013;49:5666-8.

[132] Nagaraju D, Bhagat DG, Banerjee R, Kharul UK. In situ growth of metal-organic frameworks on a porous ultrafiltration membrane for gas separation. Journal of Materials Chemistry A. 2013;1:8828-35.

[133] Mao Y, Li J, Cao W, Ying Y, Sun L, Peng X. Pressure-Assisted Synthesis of HKUST-1 Thin Film on Polymer Hollow Fiber at Room Temperature toward Gas Separation. ACS Applied Materials \& Interfaces. 2014;6:4473-9.

[134] Li W, Meng Q, Zhang C, Zhang G. Metal-Organic Framework/PVDF Composite Membranes with High $\mathrm{H}_{2}$ Permselectivity Synthesized by Ammoniation. 2015;21:7224-30.

[135] Hurrle S, Friebe S, Wohlgemuth J, Wöll C, Caro J, Heinke L. Sprayable, Large-Area Metal-Organic Framework Films and Membranes of Varying Thickness. 2017;23:2294-8.

[136] Li Y-S, Liang F-Y, Bux H, Feldhoff A, Yang W-S, Caro J. Molecular Sieve Membrane: Supported Metal-Organic Framework with High Hydrogen Selectivity. 2010;49:548-51.

[137] Li Y, Liang F, Bux H, Yang W, Caro J. Zeolitic imidazolate framework ZIF-7 based molecular sieve membrane for hydrogen separation. Journal of Membrane Science. 2010;354:48-54.

[138] Aceituno Melgar VM, Kwon HT, Kim J. Direct spraying approach for synthesis of ZIF7 membranes by electrospray deposition. Journal of Membrane Science. 2014;459:190-6.

[139] Hillman F, Brito J, Jeong H-K. Rapid One-Pot Microwave Synthesis of Mixed-Linker Hybrid Zeolitic-Imidazolate Framework Membranes for Tunable Gas Separations. ACS Applied Materials \& Interfaces. 2018;10:5586-93.

[140] Chang H, Wang Y, Xiang L, Liu D, Wang C, Pan Y. Improved $\mathrm{H}_{2} / \mathrm{CO}_{2}$ separation performance on mixed-linker ZIF-7 polycrystalline membranes. Chemical Engineering Science. 2018;192:85-93.

[141] McCarthy MC, Varela-Guerrero V, Barnett GV, Jeong H-K. Synthesis of Zeolitic Imidazolate Framework Films and Membranes with Controlled Microstructures. Langmuir. 2010;26:14636-41.

[142] Bux H, Feldhoff A, Cravillon J, Wiebcke M, Li Y-S, Caro J. Oriented Zeolitic Imidazolate Framework-8 Membrane with Sharp $\mathrm{H}_{2} / \mathrm{C}_{3} \mathrm{H}_{8}$ Molecular Sieve Separation. Chemistry of Materials. 2011;23:2262-9.

[143] Yao J, Dong D, Li D, He L, Xu G, Wang H. Contra-diffusion synthesis of ZIF-8 films on a polymer substrate. Chemical Communications. 2011;47:2559-61.

[144] Pan Y, Wang B, Lai Z. Synthesis of ceramic hollow fiber supported zeolitic imidazolate framework-8 (ZIF-8) membranes with high hydrogen permeability. Journal of Membrane Science. 2012;421-422:292-8.

[145] Fan L, Xue M, Kang Z, Li H, Qiu S. Electrospinning technology applied in zeolitic imidazolate framework membrane synthesis. Journal of Materials Chemistry. 2012;22:252726.

[146] He M, Yao J, Li L, Zhong Z, Chen F, Wang H. Aqueous solution synthesis of ZIF-8 films on a porous nylon substrate by contra-diffusion method. Microporous and Mesoporous Materials. 2013;179:10-6.

[147] Huang K, Dong Z, Li Q, Jin W. Growth of a ZIF-8 membrane on the inner-surface of a ceramic hollow fiber via cycling precursors. Chemical Communications. 2013;49:10326-8.

[148] Zhang X, Liu Y, Kong L, Liu H, Qiu J, Han W, et al. A simple and scalable method for preparing low-defect ZIF-8 tubular membranes. Journal of Materials Chemistry A. 2013;1:10635-8.

[149] Shekhah O, Swaidan R, Belmabkhout Y, du Plessis M, Jacobs T, Barbour LJ, et al. The liquid phase epitaxy approach for the successful construction of ultra-thin and defect-free ZIF- 
8 membranes: pure and mixed gas transport study. Chemical Communications. 2014;50:208992.

[150] Liu Y, Wang N, Pan JH, Steinbach F, Caro J. In Situ Synthesis of MOF Membranes on $\mathrm{ZnAl}-\mathrm{CO}_{3}$ LDH Buffer Layer-Modified Substrates. Journal of the American Chemical Society. 2014; 136:14353-6.

[151] Zhang X, Liu Y, Li S, Kong L, Liu H, Li Y, et al. New Membrane Architecture with High Performance: ZIF-8 Membrane Supported on Vertically Aligned ZnO Nanorods for Gas Permeation and Separation. Chemistry of Materials. 2014;26:1975-81.

[152] Li J, Cao W, Mao Y, Ying Y, Sun L, Peng X. Zinc hydroxide nanostrands: unique precursors for synthesis of ZIF-8 thin membranes exhibiting high size-sieving ability for gas separation. CrystEngComm. 2014;16:9788-91.

[153] Su P, Li W, Zhang C, Meng Q, Shen C, Zhang G. Metal based gels as versatile precursors to synthesize stiff and integrated $\mathrm{MOF} /$ polymer composite membranes. Journal of Materials Chemistry A. 2015;3:20345-51.

[154] Drobek M, Bechelany M, Vallicari C, Abou Chaaya A, Charmette C, Salvador-Levehang $\mathrm{C}$, et al. An innovative approach for the preparation of confined ZIF-8 membranes by conversion of ZnO ALD layers. Journal of Membrane Science. 2015;475:39-46.

[155] Liu Y, Peng Y, Wang N, Li Y, Pan JH, Yang W, et al. Significantly Enhanced Separation using ZIF - 8 Membranes by Partial Conversion of Calcined Layered Double Hydroxide Precursors. 2015;8:3582-6.

[156] Liu Y, Pan JH, Wang N, Steinbach F, Liu X, Caro J. Remarkably Enhanced Gas Separation by Partial Self-Conversion of a Laminated Membrane to Metal-Organic Frameworks. 2015;54:3028-32.

[157] Hu P, Yang Y, Mao Y, Li J, Cao W, Ying Y, et al. Room temperature synthesis of ZIF8 membranes from seeds anchored in gelatin films for gas separation. CrystEngComm. 2015;17:1576-82.

[158] Hu Y, Wei J, Liang Y, Zhang H, Zhang X, Shen W, et al. Zeolitic Imidazolate Framework/Graphene Oxide Hybrid Nanosheets as Seeds for the Growth of Ultrathin Molecular Sieving Membranes. 2016;55:2048-52.

[159] Shamsaei E, Lin X, Wan L, Tong Y, Wang H. A one-dimensional material as a nanoscaffold and a pseudo-seed for facilitated growth of ultrathin, mechanically reinforced molecular sieving membranes. Chemical Communications. 2016;52:13764-7.

[160] Cacho-Bailo F, Caro G, Etxeberría-Benavides M, Karvan O, Téllez C, Coronas J. MOFpolymer enhanced compatibility: post-annealed zeolite imidazolate framework membranes inside polyimide hollow fibers. RSC Advances. 2016;6:5881-9.

[161] Hou J, Sutrisna PD, Zhang Y, Chen V. Formation of Ultrathin, Continuous MetalOrganic Framework Membranes on Flexible Polymer Substrates. 2016;55:3947-51.

[162] Chernikova V, Shekhah O, Eddaoudi M. Advanced Fabrication Method for the Preparation of MOF Thin Films: Liquid-Phase Epitaxy Approach Meets Spin Coating Method. ACS Applied Materials \& Interfaces. 2016;8:20459-64.

[163] Wang X, Sun M, Meng B, Tan X, Liu J, Wang S, et al. Formation of continuous and highly permeable ZIF-8 membranes on porous alumina and zinc oxide hollow fibers. Chemical Communications. 2016;52:13448-51.

[164] Shamsaei E, Lin X, Low Z-X, Abbasi Z, Hu Y, Liu JZ, et al. Aqueous Phase Synthesis of ZIF-8 Membrane with Controllable Location on an Asymmetrically Porous Polymer Substrate. ACS Applied Materials \& Interfaces. 2016;8:6236-44.

[165] Hu Y, Wu Y, Devendran C, Wei J, Liang Y, Matsukata M, et al. Preparation of nanoporous graphene oxide by nanocrystal-masked etching: toward a nacre-mimetic metalorganic framework molecular sieving membrane. Journal of Materials Chemistry A. 2017;5:16255-62. 
[166] Li W, Su P, Li Z, Xu Z, Wang F, Ou H, et al. Ultrathin metal-organic framework membrane production by gel-vapour deposition. Nature Communications. 2017;8:406.

[167] He G, Dakhchoune M, Zhao J, Huang S, Agrawal KV. Electrophoretic Nuclei Assembly for Crystallization of High-Performance Membranes on Unmodified Supports. 2018;28:1707427.

[168] Cacho-Bailo F, Matito-Martos I, Perez-Carbajo J, Etxeberría-Benavides M, Karvan O, Sebastián V, et al. On the molecular mechanisms for the $\mathrm{H}_{2} / \mathrm{CO}_{2}$ separation performance of zeolite imidazolate framework two-layered membranes. Chemical Science. 2017;8:325-33.

[169] Kang Z, Fan L, Wang S, Sun D, Xue M, Qiu S. In situ confinement of free linkers within a stable MOF membrane for highly improved gas separation properties. CrystEngComm. 2017;19:1601-6. 